\title{
Recreating the South Sea Bubble: Lessons from an Experiment in Financial History
}

\author{
Giovanni Giusti \\ Universitat Pompeu Fabra
}

\author{
Charles Noussair \\ University of Tilburg
}

\author{
Hans-Joachim Voth \\ ICREA-Universitat \\ Pompeu Fabra and CREi
}

\begin{abstract}
Major bubble episodes are rare events. In this paper, we examine what factors might cause some asset price bubbles to become very large. We recreate, in a laboratory setting, some of the specific institutional features investors in the South Sea Company faced in 1720. Several factors have been proposed as potentially contributing to one of the greatest periods of asset overvaluation in history: an intricate debt-for-equity swap, deferred payment for these shares, and the possibility of default on the deferred payments. We consider which aspect might have had the most impact in creating the South Sea bubble. The results of the experiment suggest that the company's attempt to exchange its shares for government debt was the single biggest contributor to the stock price explosion, because of the manner in which the swap affected fundamental value. Issuing new shares with only partial payments required, in conjunction with the debtequity swap, also had a significant effect on the size of the bubble. Limited contract enforcement, on the other hand, does not appear to have contributed significantly.
\end{abstract}

Keywords: Financial bubbles, experiments, South Sea bubble, risk-shifting, government debt, equity issuance ${ }^{1}$

IEL codes: G01, G12, G14, N23, C92.

\footnotetext{
${ }^{1}$ We thank participants at the BGSE forum, the 2013 Experimental Finance Conference, the 2013 Society for the Advancement of Economic Theory Meetings, and the 2013 Economic Science Association for their comments and suggestions. We are grateful to the CentER of Economic Research at Tilburg University for financial support.
} 


\section{Introduction}

From the Dutch Tulipmania of the $17^{\text {th }}$ century to the NASDAQ bubble, the rise and fall of speculative bubbles has produced massive gains and losses for investors. As the financial crisis of 2007-08 has demonstrated, bubbles can also be a major source of economic instability. Large swings in asset prices over short periods of time have often been considered as a sign of inefficiency and a telling testament to the "irrational exuberance" of investors. One important strand in the literature denies the existence of bubbles altogether (Garber 2001; Fama 1965). Other scholars have sought to explain their emergence as a result of risk shifting, investor inexperience, and limitations of market micro-structure such as an inability to short over-valued stocks (Allen and Gale 2000; Greenwood and Nagel 2009; Hong, Scheinkman, and Xiong 2006; Lintner 1971). Empirical work has demonstrated that sophisticated investors - instead of attacking mispricing often "ride" bubbles, aggravating price swings (Brunnermeier and Nagel 2004; Temin and Voth 2004). The experimental evidence shows that the size and duration of bubbles are sensitive to the exact incentives in place (see Palan 2013 for a review of this literature).

While the theoretical and empirical literature offers explanations for the continuation of mispricing, the origins of bubbles are less well-understood. Experimental work suggests that bubbles emerge readily in laboratory settings (Smith, Suchanek, and Williams 1988). This makes it all the more puzzling that major bubbles have only erupted on a handful of occasions over the last 400 years, such as during the Tulipmania, the South Sea bubble, and the NASDAQ episodes. Milton Friedman (2001) concluded that "...the start and end of a bubble just cannot be explained rationally."

In this paper, we report the results of a laboratory experiment designed to study which specific, institutional features might have played a role in igniting the South Sea mania of 1720. Many historical features cannot be recreated. Nevertheless, if an institution exerts a systematic effect on mispricing in our experiments, some 400 years after the event, we argue that it is likely to have played an important role in the original episode. Because our interest is in understanding a specific historical episode, we do not adhere closely to any previously studied paradigm, but rather develop a new experimental design that is tailored to the purpose of our study.

Together with the Tulipmania and the Mississippi Bubble, the South Sea bubble is one of the three famous, early bubbles that occurred during the $17^{\text {th }}$ and $18^{\text {th }}$ 
centuries (Carswell 1960; Dale 2004) . It is among both the best-documented and the least well-understood episodes in the history of financial markets. ${ }^{2}$ Originally created to trade with Spanish America, the South Sea Company's main source of revenue was interest payments from its holding of UK government bonds. In 1719 , it proposed to swap all outstanding government debt for its own equity. After the contract was awarded by Parliament, it began to issue new stock through subscriptions. Eventually, it exchanged government debt for equity. The South Sea Company's stock rose in value from a little more than $£ 120$ at the start of the year 1720 to nearly $£ 1,000$ in June, before crashing by some 80 percent before year-end (figure 1). While other stocks also saw their prices surge, the sheer scale and speed of the South Sea Company's price explosion and decline are without parallel. ${ }^{3}$ The South Sea bubble did not only matter for investors at the time. As a result of lobbying by the company, when the stock price was near its peak, England effectively prohibited the issuance of shares in new companies. This closed the stock market to firms for over a century, resulting in markedly greater difficulties in raising funds for new ventures (Harris 1994; Temin and Voth 2013).

${ }^{2}$ One example demonstrating the extent of disagreement is the debate between Shea (2007)and R. S. Dale, Johnson, and Tang (2005).

${ }^{3}$ Temin and Voth (2004) compare the magnitude of the price run-up and decline in the South Sea and the NASDAQ bubble, and find the former to be markedly larger. 
Share prices of major listed corporations, England, 1719-1723

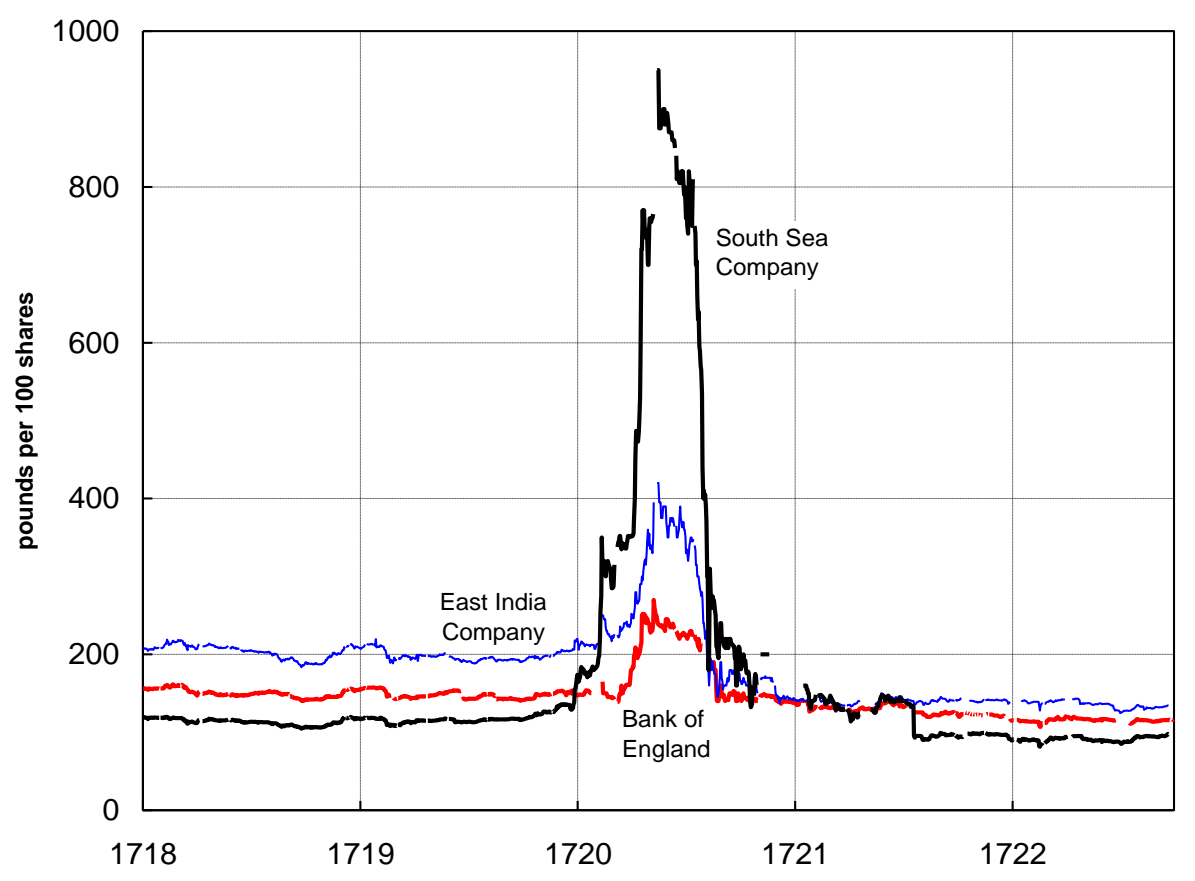

Figure 1: Share prices of major listed corporations, England, 1719-1723

The institutional features of the historic South Sea scheme inform our choice of experimental treatments. The explosion in the South Sea Company's stock price took place when (1) it was seeking to swap government debt for equity, (2) allowed investor to purchase shares while deferring payment of most of the purchase price, and (3) had limited ability to enforce collection of the deferred payments. We examine all these specific features in isolation. The baseline treatment of our design includes all of these features and generates a large bubble. In the other treatments, we remove the institutional features (1) - (3), one at a time. The magnitude of the bubble in these treatments is compared to that in the baseline treatment. In this manner, we are able to identify which aspects likely contributed to one of the greatest and most famous bubbles in history.

Our paper makes two main contributions. The first is substantive: Our key finding is in providing evidence about what factors might have been responsible for the eruption of one of history's greatest bubbles. Our findings suggest that the attempt to swap government debt for company equity was the single most important contributing factor to the South Sea bubble. In addition, the ability to defer payment of shares helped to increase the likelihood of a bubble forming, and increased its size. Limited contract enforcement played a markedly smaller role. The second contribution is methodological: We use the laboratory to try to 
understand a specific episode in economic history, recreating incentives agents faced nearly 400 years ago. We exploit the possibility, offered by laboratory experimentation, to observe the fundamental value and thus measure the magnitude of a bubble, to introduce and remove institutional features keeping all else constant, and to generate new data designed to reproduce conditions that ceased to exist hundreds of years ago. We view this last feature as particularly beneficial to the study of economic history.

The paper proceeds as follows. Section II summarizes the historical context and background of the South Sea bubble. Section III presents our experimental design and describes how we capture the essential historical details of trading "in the South Seas" (as contemporaries would have said). In Section IV, we show our results, and Section V concludes.

\section{Section II: Historical Context and Background}

The South Sea Company was founded to trade with South America. The Peace Treaty of Utrecht in 1713, which brought the War of the Spanish Succession to an end, granted Britain the right to send trading ships periodically to Spain's possessions in the Americas. The company took over some of the government's debt in exchange for the trading privileges. Its mercantile operations never amounted to much. By the late 1710s, the South Sea Company amounted to little more than a shell company distributing interest payments on government debt to its shareholders.

In 1719 , the Company took over another part of the national debt, referred to as the "lottery loan". While paying a high rate of interest, the loan was highly illiquid. Bonds could not readily be transferred; price discounts were substantial. The operation that swapped these government bonds for equity in the South Sea Company was widely considered a success - the investors gained a more liquid asset, the government lowered the interest charges on its debt, and the company made a profit.

The 1720 scheme was vastly more ambitious - and it contained one crucial difference with the 1719 operation. The South Sea Company proposed to take over the entire remaining national debt (except for the parts held by the Bank of England and the East India Company). Instead of swapping debt for equity at a pre-established price, the company remained vague as to the exchange ratio. This implied that as the stock price appreciated, more debt could be bought for each share. 
Bidding against the Bank of England for the right to do the debt conversion, the South Sea Company finally won the contract in a parliamentary vote in 1720 . Massive bribery preceded the award of the contract. By this stage, the stock price had more than doubled. After the award of the contract, the South Sea Company began to issue new shares in repeated rounds of offerings. It did so at steadily rising prices - for $£ 300$ in early April, $£ 400$ in late April, $£ 1,000$ in June, and $£ 1,000$ in August. These were known as "subscriptions", and were bought on installment plans. Actual down payments amounted to only $£ 40-200$ (10-20\% of the total cost). Subscribers did not become owners of shares until all payments had been made. Subscription receipts could themselves be traded. Their prices moved in parallel with the price of the underlying stock, but in relative terms, price changes were magnified - as they are with options. ${ }^{4}$

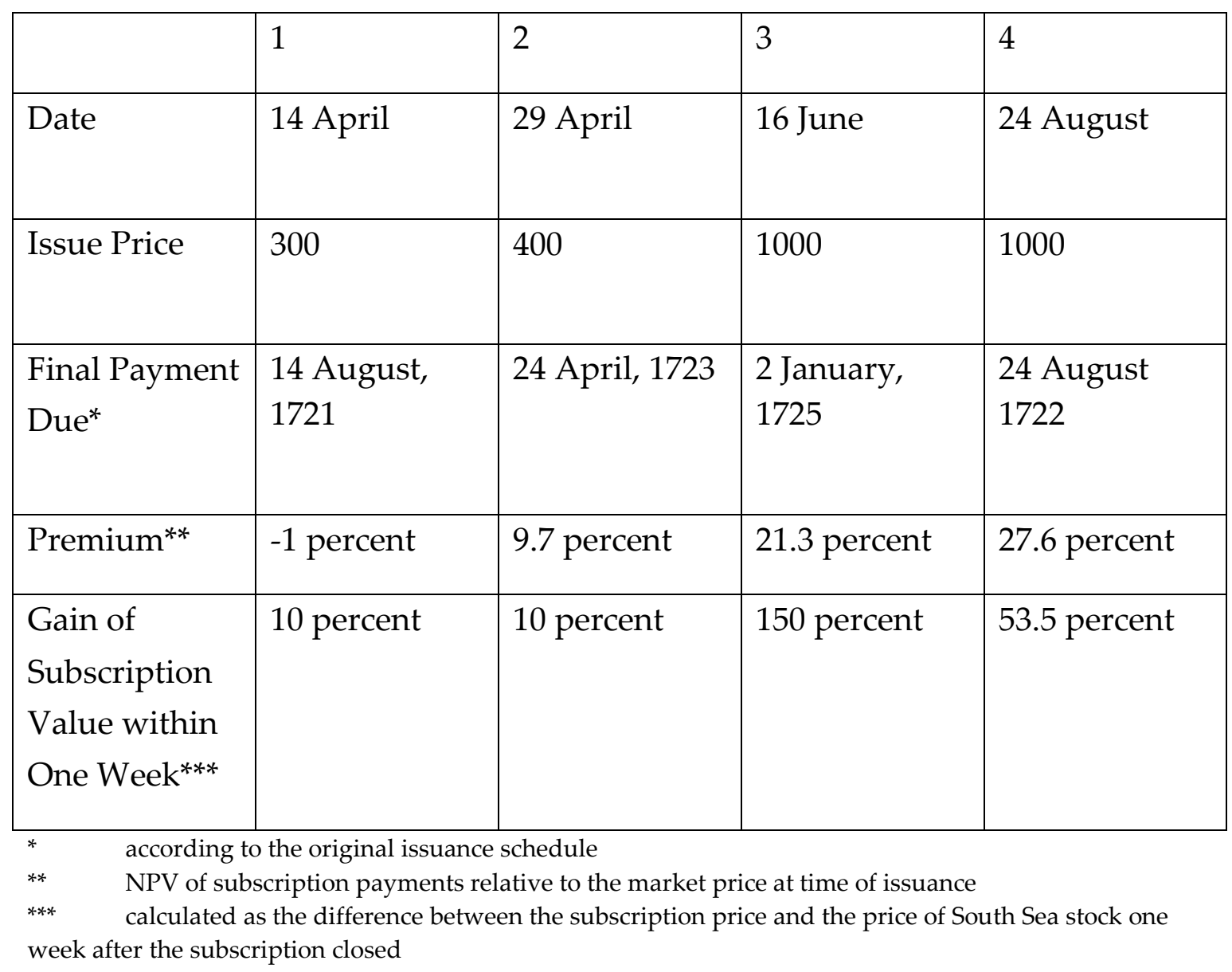

Table 1: South Sea Company Issues of New Shares, 1720

${ }^{4}$ For the exact details of the analogy with options pricing, cf. Shea (2007) 
Throughout the spring and summer of 1720, the stock price moved up, reaching nearly $£ 1,000$ by June. Many other stock schemes sprang up during the same time, luring investors. Also, many inexperienced investors entered the market, often in the expectation of a quick profit. The company initially did not use the proceeds from share issues to actually buy back government bonds, as the original scheme had envisaged. Instead, it lent generously against its own shares. Many of these loans were later not repaid.

The actual exchange of government debt for equity took place in May and in August. Eventually, in the spring, the company began to offer bond holders a chance to exchange bonds for South Sea stock. Terms were not overly generous, but a significant share of bondholders nonetheless accepted the deal. As the stock price increased, existing bonds could be bought in exchange for fewer share certificates. This increased the intrinsic value of the stock. In other words, the rise in the stock price, the issuance of new shares, and the possibility of buying out debt holders created winners and losers (Carswell 1993 : 120). Contemporaries were keenly aware of this fact. As a matter of fact, a Member of Parliament Archibald Hutcheson - published several pamphlets in the course of 1720, pointing out the losses and gains to different subscribers and the original bondholders, as a function of when they had bought.

One of the tables published by Hutcheson is reproduced as Table 2. We see that in the fall of 1720 - after the second subscription of shares at $£ 1,000$ per 100 shares had closed - there were clear winners and losers. Column 1 gives the proportion of the stock held by different groups - the old proprietors, who bought South Sea stock at a $£ 100$, and the subscribers, who had bought at increasing prices. The company had issues shares for a nominal value of $£ 42$ million. In the aggregate, it had sold them to the public for $£ 234$ million, or $£ 557$ per 100 shares. At the time, South Sea stock was worth close to $£ 600$. Thus, all the subscribers who paid less than this had made money; and those who had bought for $£ 1,000$ had lost. Column 2 gives, for each group, the market value of stock held; column 3 summarizes what investors paid for it. The magnitude of gains and losses is summarized in column 4. Some $£ 90$ million of losses accrued to the new subscribers at $£ 1,000$. Most of these ended up in the pockets of the old proprietors ( $£ 57$ million) and, in much smaller quantities, in those of the early subscribers. 


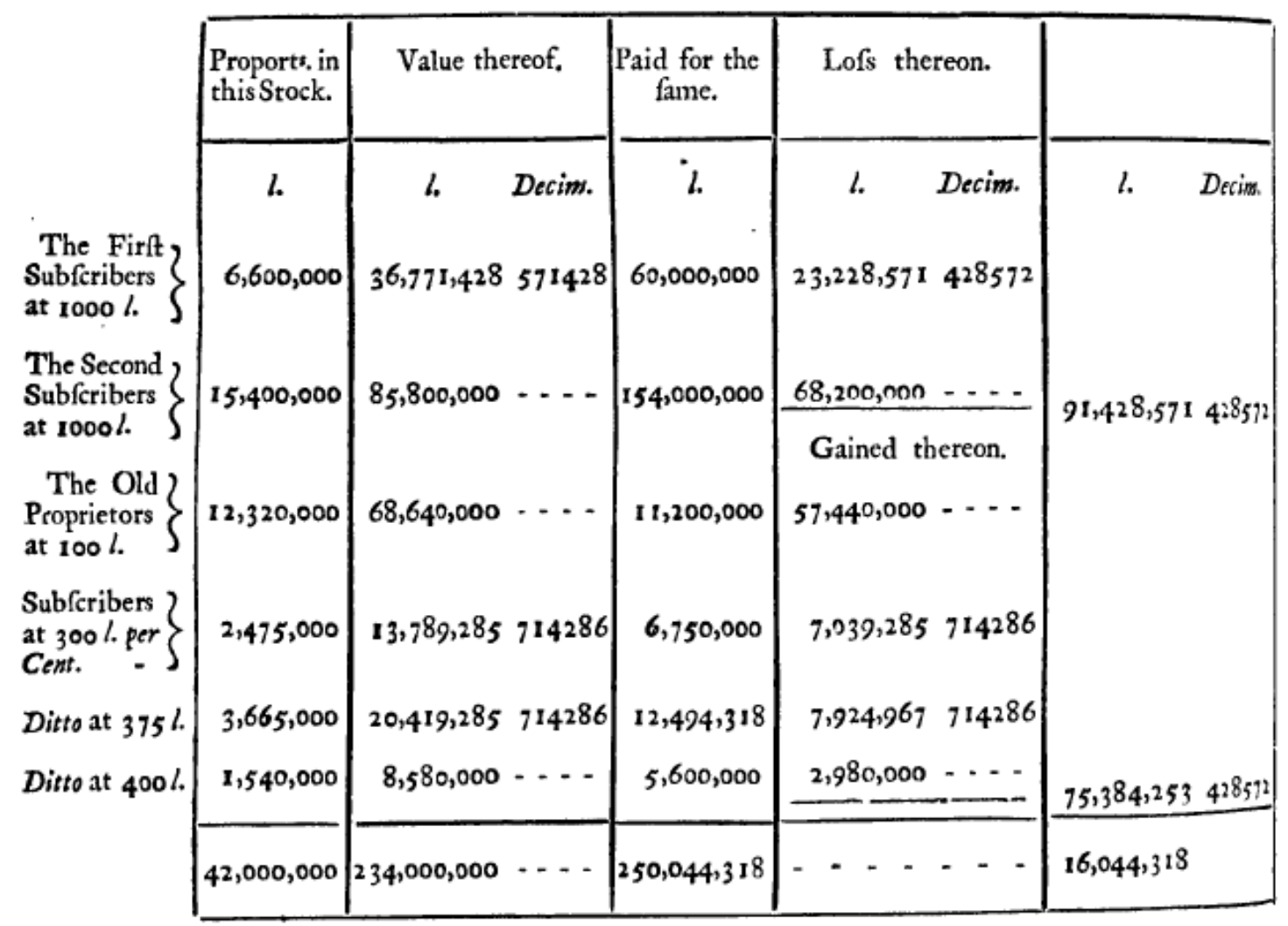

Table 2: Winners and Losers from the South Sea Conversion Scheme Source: Archibald Hutcheson (1720)

The basic principle that ensured that investors put their money into the South Sea scheme was simple enough. The expected losses and gains for various groups, as set out in detail by Hutcheson, could not have remained a secret. One key question is then why the new owners bought shares which gave them cash flow rights that were lower than their market price? Put simply, an investor in 1720 could acquire the rights to future interest payments by buying a government bond, or by buying South Sea stock. Why pay more for the latter? One logical possibility is that some commercial venture might produce vast profits. This was highly unlikely.

Our answer is that new subscribers could possibly benefit from rising inherent values of their shares as a result of additional stock issuance in the future - again, if bondholders could be bought out more cheaply, the intrinsic value of shares would increase. Note that for this mechanism to work no actual purchase of bonds is necessary - it is enough that it is planned. New investors are willing to buy because they hope that they will gain if prices continue on an upward trend (which then translates into a self-fulfilling prophecy). The prospect of future 
issuance can turn the loss in the present into a purchase that, at least in expectation, can turn out to be profitable at some point in the future.

The structure we just described is, of course, that of a classic Ponzi scheme. The secret to success is to join early (and to get out before things fall apart). As long as there is a good chance that another wave of investors will enter, it is a good idea to participate. The details of the South Sea operations were complex, and there is some evidence that investors and the general public did not find it easy to see through it all. The Flying Post, a newspaper at the time, argued on April 9, 1720 that the intrinsic value of the South Sea Company stock would be $£ 448$ if the share price went to $£ 300$. At $£ 600$, it would be $£ 880$. We do not know how these numbers were calculated; it is clear that they cannot be correct. The basic structure is right, with higher share prices justifying a higher fundamental. At the same time, the relative prices are wrong - the intrinsic value in this operation can never catch up with the price at which the last issue was undertaken.

Based on the historical background described above, it is possible to distill a number of hypotheses about the factors that might have contributed to one of the biggest bubbles in history:

\section{Hypothesis 1: Redistributing revenue from new issues to existing shareholders increases prices and bubble magnitude.}

As indicated earlier, the redistribution of new revenues to existing shareholders, in the form of interest payments on the bonds purchased with these revenues, increased the return to existing shareholders. This increase in fundamental values could launch a bubble, in which prices depart from intrinsic values. This could occur, for example, if heterogeneous beliefs about the likelihood of future issues lead to those with the most optimistic beliefs about future issues to bid up the price. Furthermore, the increases in price could attract the attention of momentum traders who bid up prices, merely because they expect past price trends to continue. Speculators may attempt take advantage of the presence of momentum traders, bid up prices further, and magnify a bubble.

\section{Hypothesis 2: When new shares issues can be paid for in installments, bubbles are greater than when they must be fully paid for up front.}

The possibility of payment by installment would, in principle, relax cash constraints on those individuals who are speculating on future new share issues. This would allow them to take larger long positions, possibly inflating a bubble. 
Furthermore, deferment of payment for new shares allows greater leverage for investors who are speculating on a rising market. Consider an individual who is interested in a purchase for later resale, and who expects the price to appreciate by $20 \%$ between period $t$ and $t+1$. If deferment of payment is not feasible and he purchases and resells, his return is simply $20 \%$. However, if he can pay only $20 \%$ in period $\mathrm{t}$, sell for $120 \%$ of the original contract price and pay back the remaining $80 \%$ at that time, his return is $100 \%$. This leveraging effect could magnify a bubble once prices have begun to rise.

\section{Hypothesis 3: If outstanding installment payments do not have to be paid back at the end of the life of the asset, bubbles are greater than if they do have to be paid.}

The ability to purchase in installments increases the capacity to speculate on future price increases. If the resulting debt does not have to be paid back, it lowers the downside risk of holding the asset. If prices fall to a level below the amount the individual owes, she might find it more profitable to default on her remaining installment payments and give up the share. Thus, if prices are volatile, the default option gives the asset the properties of a call option, limiting downside risk in a similar manner. In our experiment, we implement the possibility of default by nullifying any outstanding debts owed at the end of the life of the asset. If traders take this effect into account, it could increase demand for the asset when future prices are unpredictable, and thus exacerbate any bubbles that occur. ${ }^{5}$

\section{Section III: Experimental Design}

\section{III.A Procedures Common to All Treatments}

\section{i. $\quad$ General Structure}

The experiment consisted of four treatments, called Baseline, NoInstall, NoDefault, and NoSwap. We conducted eight sessions for the baseline treatment and four sessions for each of the other three treatments, for a total of 20 sessions. The sessions were conducted at University Pompeu Fabra and Tilburg

\footnotetext{
${ }^{5}$ Here, the intuition is similar to the one in recent work that explores the analogy between options pricing and stock prices under high uncertainty (Pastor and Veronesi 2006).
} 
University. ${ }^{6}$ Each session consisted of two consecutive horizons, with each horizon made up of a sequence of between ten and twenty 150-second periods. At the beginning of the second horizon, endowments were reinitialized to the levels at the beginning of the first. ${ }^{7}$ This means that the two horizons can be viewed as two distinct economies, linked only by the experience participants accumulate in during the first horizon.

When subjects arrived at the laboratory, they received approximately 45 minutes of instructions. They were instructed in both the use of the computer software and the specific conditions for each treatment. All traders took on the role of traders, with the ability to both purchase and sell the asset. Thereafter, they familiarized themselves with the game by trading during a practice phase in which there was one auction of new shares and three periods of trading of shares. Thereafter, the first trading session began. ${ }^{8}$

In each period, up to two markets could operate simultaneously (Screen 1 in appendix). In Market $\mathrm{A}$, the shares originally issued at the beginning of the trading session could be exchanged. That is, market A served for trading those shares traders in circulation at the outset of the first period of a horizon. Market $B$ enabled trading of newly-issued shares. New shares could be issued in any period, beginning in period four. Shares trading in market A and market B were

6 The sessions were conducted at University Pompeu Fabra (17 sessions) and at Tilburg University (3 sessions) between July 2012 and December 2012. Each session took approximately 2 hours and 40 minutes. The average payment was 9 Euros per hour at UPF and 13 Euros per hour at Tilburg.

${ }^{7}$ We use the term session in this paper in the manner in which it is typically employed in experimental economics, which differs from common usage in finance. In experimental economics, a session refers to a continuous time interval in which a particular cohort is present in the laboratory. The sessions of our experiment are divided up into two trading horizons. The horizons are independent of each other, in that all the beginning of the second horizon all parameters are reinitialized and the only link between the two horizons is the possible effect of subjects' prior experience in the first horizon on behavior in the second. Each horizon is divided up into periods. A trader's cash and asset position at the end of one period carry over to the next period within the same horizon. Thus, according to one common notion in finance, a period in our experiment corresponds to a trading session. However, in this paper, we maintain the usage of the term conventional in experimental economics.

8 Participants were graduate and undergraduate students in various majors, but most were majoring in business and economics. No subjects had previously participated in any asset market experiment. The number of subjects participating in each session ranged from 6 to 10 . 
identical in terms of the dividends paid and expected lifetime and therefore in terms of their fundamental values. ${ }^{9}$

The markets were organized using continuous double auction rules (Smith 1962), and implemented with the z-tree computer software (Fischbacher 2007). Trade took place in terms of an experimental currency, called "ducats", which was converted into Euros at the end of the experiment at a conversion rate that was common knowledge.

\section{ii. $\quad$ The Asset}

At the end of each period, each unit of the asset paid a dividend that took on one of four values, $0,8,28$, or 60 Ducats, each with equal probability. Therefore the expected dividend per period is equal to 24 Ducats. Dividend realizations were unknown until the time they were determined.

The asset had a life of multiple periods. The maximum possible lifetime was 20 periods and the minimum was 10 periods. For each period from $10-19$, whether the trading session would continue to the next period or not was determined randomly at the end of the period. The probability that the current period was the last one was equal to $1 / 6$ in each of the periods from $10-19$.

The fundamental value of both assets can be calculated at any time from the dividend and probability of termination. This fundamental value is the sum of the expected dividends to be received from the current period $t$ until the end of the life of the asset. This is given by the expression:

$$
F V_{t}=\sum_{s=t}^{T} \mathrm{~d}_{\mathrm{s}} *(1-\pi)^{T-s}
$$

Where denotes the expected dividend in period $t$ and $\pi$ is the probability that the market ends after the current period. For example, consider a fixed of 24 for each period until end of the market. The fundamental value in period 16 would be:

Ducats. Subjects were provided with a table that indicated the fundamental

\footnotetext{
${ }_{9}^{9}$ The reason for keeping asset markets separate is that during the South Sea bubble, shares and "scrib" (subscription certificates) were trading in parallel.
} 
value in each period and how it was calculated. The same table was also displayed on each subject's computer screen before the start of each trading period.

\section{iii. Initial Endowments and New Issues}

Before period 1, each subject was endowed with 5 shares and 30,000 ducats. These shares of asset could then be traded in market $\mathrm{A}$ at any time and the cash endowment could be used for new asset purchases. New issues of asset could occur in any period beginning in period 4. Issues occurred at the beginning of the period, just after the dividend in the previous period was paid and before the market opened for trade in the current period. The criterion for whether or not a new issue would take place in period $t$ was the following: If the average transaction price in market $\mathrm{B}$ was greater than the fundamental value of the preceding period, a new issue would occur. ${ }^{10}$

New shares were issued with sealed bid auctions that took place at the beginning of some periods. In each period in which there was an issue, a subject could bid for up to two shares of the K new shares offered for sale. The bids were ordered from highest to lowest and the $\mathrm{K}$ highest bidders were awarded units. Winning bidders paid a per-unit price equal to the lowest of the accepted bids, that is, the $\mathrm{K}^{\text {th }}$ highest bid. Thus the auction format is a uniform-price sealed bid auction with lowest accepted bid pricing. ${ }^{11}$ In the first period in which there is a subscription, eight shares were auctioned. In later subscription, five shares were auctioned. The criterion for issuing shares was unknown to participants.

\section{III.B The Treatments}

The treatments are designed to assess the impact of (a) swapping debt for equity, (b) deferring payment for newly-issued shares, and (c) the possibility of default on these payments, for bubble formation. The baseline treatment is characterized by the presence of all institutional features (a) - (c). Each of the other three treatments eliminates exactly one of the features (see Table 3). Consequently, we can isolate the marginal contribution of each factor when all of the others are

\footnotetext{
${ }^{10}$ In period 4, there is a subscription auction if the price in period 3 for asset $\mathrm{A}$ is greater than the fundamental value.

${ }^{11}$ While not demand-revealing, this auction format tends to generate highly efficient allocations when individuals demand is for a single unit or for two units (Alsemgeest, Noussair, and Olson 1998).
} 
present. ${ }^{12}$ Table 3 displays the features characterizing each of the treatments, and distinguishing it from the other treatments.

\begin{tabular}{lllll}
\hline \hline & Baseline & NoInstall & NoDefault & NoSwap \\
\hline Swapping & Yes & Yes & Yes & No \\
Installments & Yes & No & Yes & Yes \\
Default & Yes & No & No & Yes \\
\hline \hline
\end{tabular}

Table 3: Treatment features

\section{1) The NoInstall treatment: No payment through installments.}

In three of the treatments, an individual who purchases newly-issued shares is not required to pay the full price of the share he has bought at the time of purchase. Only $20 \%$ of the price is subtracted immediately from his current cash balance. The remaining $80 \%$ is registered as debt that the individual owes. This debt is repaid as follows: In each of four periods immediately following the period of the share issue, $20 \%$ of the price originally paid is subtracted from his cash balance. In the NoInstall treatment, newly issued shares must be paid in full at the time of purchase.

\section{2) The NoDefault treatment: Limited contract enforcement}

As explained above, the number of periods that the trading session continues is not known to traders. The session terminates with a $1 / 6$ probability at the end of each period from 10 to 19 , and with probability 1 at the end of period 20. The session may end before the debt of a trader from a purchase of new shares in the auction has been fully repaid. Students were informed that they would not have to repay any debts

\footnotetext{
${ }^{12}$ Notice that the absence of payment in installments automatically implies that default was impossible. However this does not cause problems of inference, because we are still able to disentangle the effect of each single factor.
} 
outstanding at the time a session ends. In other words, the debt owed is not subtracted from her cash holdings at the end of the trading session. In the NoDefault treatment, the amount due is subtracted in full from his cash account when a session ends.

In the market for the South Sea shares, the default option was typically exercised during the crash because the market value of the shares fell below the level of the installments investors owed. In the experiment, we did not allow investors to voluntarily default at any time, as this would have been an additional demand on subjects who were already in a relatively complicated experiment. We instead implemented the default automatically at the end of the horizon, when all individuals would clearly prefer to default. This setup retains scope for the possibility of defaulting to increase bubble magnitude, since it can be expected to increase demand considerably near the end of the horizon when the default probability is relatively high.

3) The NoSwap treatment: Distribution of revenue from new share issues to existing shareholders.

There was no direct swapping of shares for equity. Instead, we created a similar effect on incentives by supplementing the dividend payment to shareholders with revenue from new shares. Our setup makes the Ponzischeme nature of the South Sea scheme clearer, but it leaves the key payoff features intact. While the mechanics "in the background" are different, the direct recycling of payments creates an analogous effect to using the revenue from new shares to purchase government bonds and transferring the interest payments to shareholders. In three of the treatments, each time that new shares were issued, $15 \%$ of the new revenue from the issue was distributed to existing shareholders in proportion to their total share holdings. For example, if there are 20 shares outstanding and 5 more are issued for 1000 each, then 750 is given out in total in the current period, 37.5 to the holder of each outstanding share. This supplement of $15 \%$ of the revenue from the issue continues to be paid in each period for the remainder of the horizon. This new dividend is added directly to the random dividend originally paid on the share. Because the fundamental value of a share is the discounted stream of future dividends, the 
fundamental value increases after each new subscription. ${ }^{13}$ In the NoSwap treatment, the revenue from the issue of new shares is not paid out to shareholders. This means that new issues do not contribute to the future expected dividend stream and thus do not affect fundamental values.

One feature that not included in our design is short selling. During the South Sea episode, short-sellers existed, though short selling was highly risky activity due to counterparty risk. ${ }^{14}$ The role and extent of short selling was similar in the market for South Sea shares to that in other asset markets throughout history, in which bubbles did not occur. The design here focuses on and isolates features in which the South Sea share market differed from others. In experimental markets, short-selling tends to reduce prices. Prices are lower, the larger is traders' short sale capacity, and a sufficiently large short sale capacity pushes prices to levels below fundamental values (Haruvy and Noussair, 2006). There is no reason to suppose that the effect of introducing short-selling would be any different across our four treatments. It would have the effect of pushing prices lower, and would exert a larger effect in this direction, the larger the short sale capacity.

The market for South Sea shares was characterized by heterogeneity in experience among investors. It was a setting in which there was scope for relatively sophisticated investors to try to exploit poor decisions of less sophisticated ones, such as new entrants. This is also the case for other asset markets throughout history, including those that did not see bubbles or crashes. Thus, we do not include a flow of new entrants in our design. Nevertheless, our laboratory markets, like most asset markets, are characterized by differences in trader sophistication. Traders are sampled from the student population of diverse public universities. In experimental asset markets with such populations, individuals with relatively high cognitive ability substantially outperform those with lower ability (see for example Corgnet et al., 2012, or Breaban and Noussair, 2013). In this regard, our study has the potential to reproduce the heterogeneity present in the South Sea share market. While we employ a student population obviously differing in many ways from the investors in the South Sea company, the bulk of the evidence available indicates that the behavior of students and professionals in experimental paradigms does not differ systematically (Frechette, 2009). In our experiment, in which there are two consecutive trading horizons, we are able to gather data at two different experience levels for each

${ }^{13}$ At the beginning of each period of the market, the table displayed on subjects' computer screens that indicates the future expected dividend stream, is updated accordingly.

${ }^{14}$ There were also difficulties enforcing contracts in law. Cf. Neal 2012. 
cohort. As can be seen from figures 1 and 2 in the next section, the results do not differ appreciably between horizons, particularly with regard to which treatment condition generates a greater bubble.

\section{Section IV: Results}

\section{IV.A Market outcomes}

The time series of transaction prices, as well as of the difference between transaction price and fundamentals, are shown in figure 1. Absolute transaction price time series are shown in the left panel and the excess of prices over fundamentals in the right panel. The upper half of the figure corresponds to the first horizon, and the lower half to the second horizon. Each of the series of data is the average over all four sessions of a given treatment. The data from markets A and B are pooled. ${ }^{15}$

\footnotetext{
${ }^{15}$ In principle, even though both assets are characterized by having the same fundamental value at any point in time, it is possible that their trading prices differ. In order to check for this possibility, we run a set of t-test comparisons on the pooled data from all treatments. First, we test for differences in median prices between the two markets from period 4 on. A total of 464 prices were compared (232 prices for each asset type).The differences in prices between the two markets are very small. In market $A$, the mean price is 797, with a standard deviation of 584 . In market $B$ the mean price is $=792$, with a standard deviation of 590. A t-test of whether the difference in prices is different from zero, using the pair of prices within each period as the unit of observation, yields $t=0.0987$, with $\mathrm{p}=0.9214$. Second, we run 20 independent-sample $\mathrm{t}$-tests, one for each session. Only in one out of 20 sessions do we find significantly different prices between the two markets, and in that case the difference was only present in five periods. This result that identical assets trade at identical prices is consistent with previous experimental work that shows that two assets with identical fundamental value time traded simultaneously do not generate significantly different price patterns (Fisher and Kelly, 2000).
} 

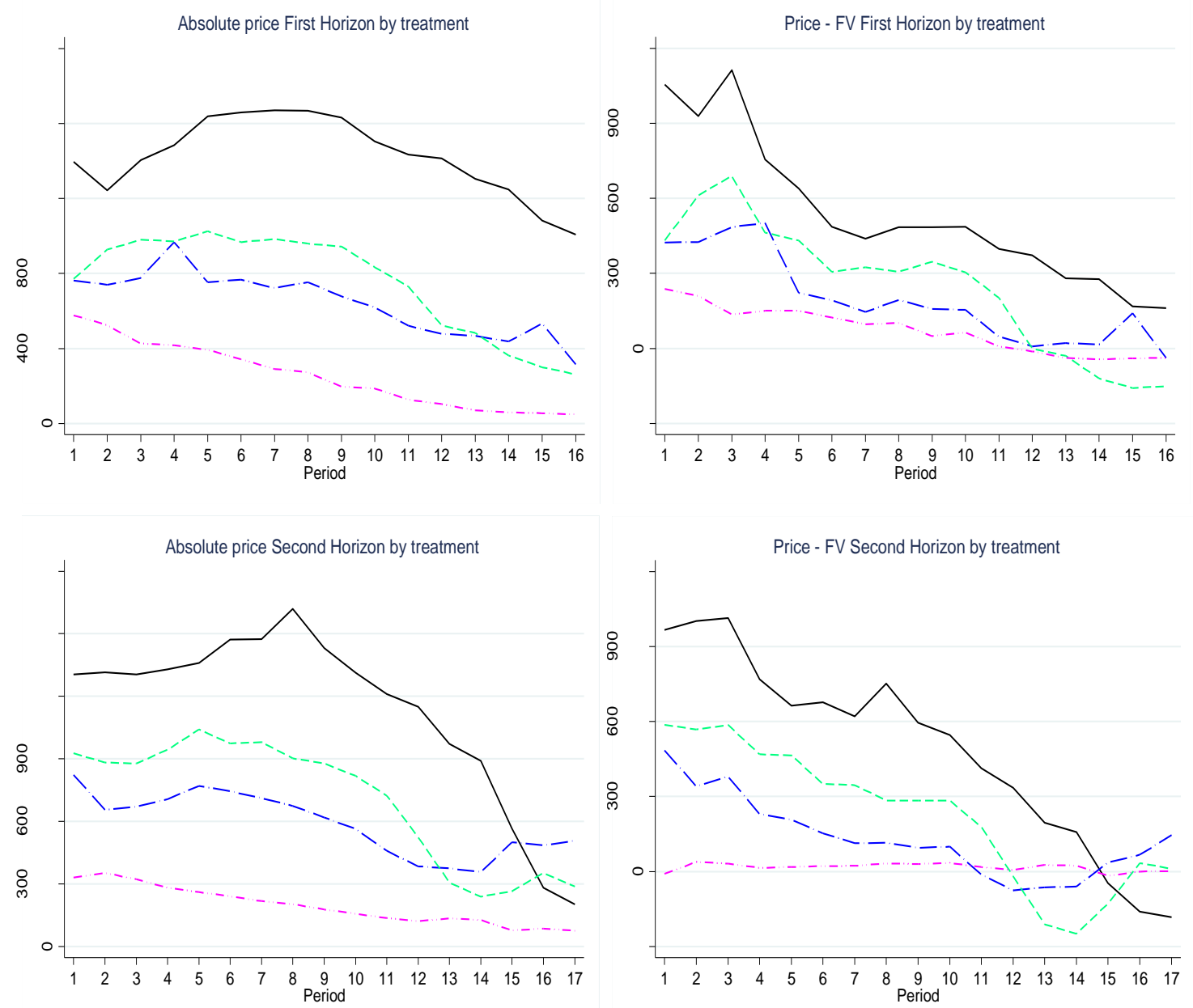

Figure 1. Left panel: Absolute transaction price by treatment. Right panel: Transaction price minus fundamental value by treatment. Top panel: First horizon. Bottom panel: Second horizon.

Some consistent patterns are evident in the figures. ${ }^{16}$ The first is that the Baseline treatment exhibits prices much greater than fundamental values, as well as the highest prices among any of the treatments. This suggests that each of the three

${ }^{16}$ In the absence of a swap, the fundamental value declines over time due to the decreasing future expected lifetime of the asset. Swapping debt for equity increases the fundamental value of the asset, offsetting this effect to some extent. 
factors contributes to a bubble. The second pattern is that prices are lowest and closest to fundamental values in the NoSwap treatment. Indeed, in the second horizon, prices in the NoSwap treatment closely track fundamentals. This indicates that the paying out of revenues from new issues to existing shareholders is the most substantial factor in creating the bubble we have observed in our experiment. This suggests that the swapping of equity for government bonds was the most important contributor to a bubble during the South Sea episode.

The differences between treatments are similar in the two horizons. The Baseline treatment generates the largest bubble, followed by the NoDefault, the NoInstall, and lastly the NoSwap treatments. The differences tend to be more pronounced and of generally greater magnitude in the first trading horizon. The price dynamics, relative to fundamentals, follow a similar pattern in three of the treatments, with a price boom in early periods and steep price declines late in the session the typical dynamic. The exception is the NoSwap treatment, in which prices tend to track fundamental values closely. 


\section{Baseline}
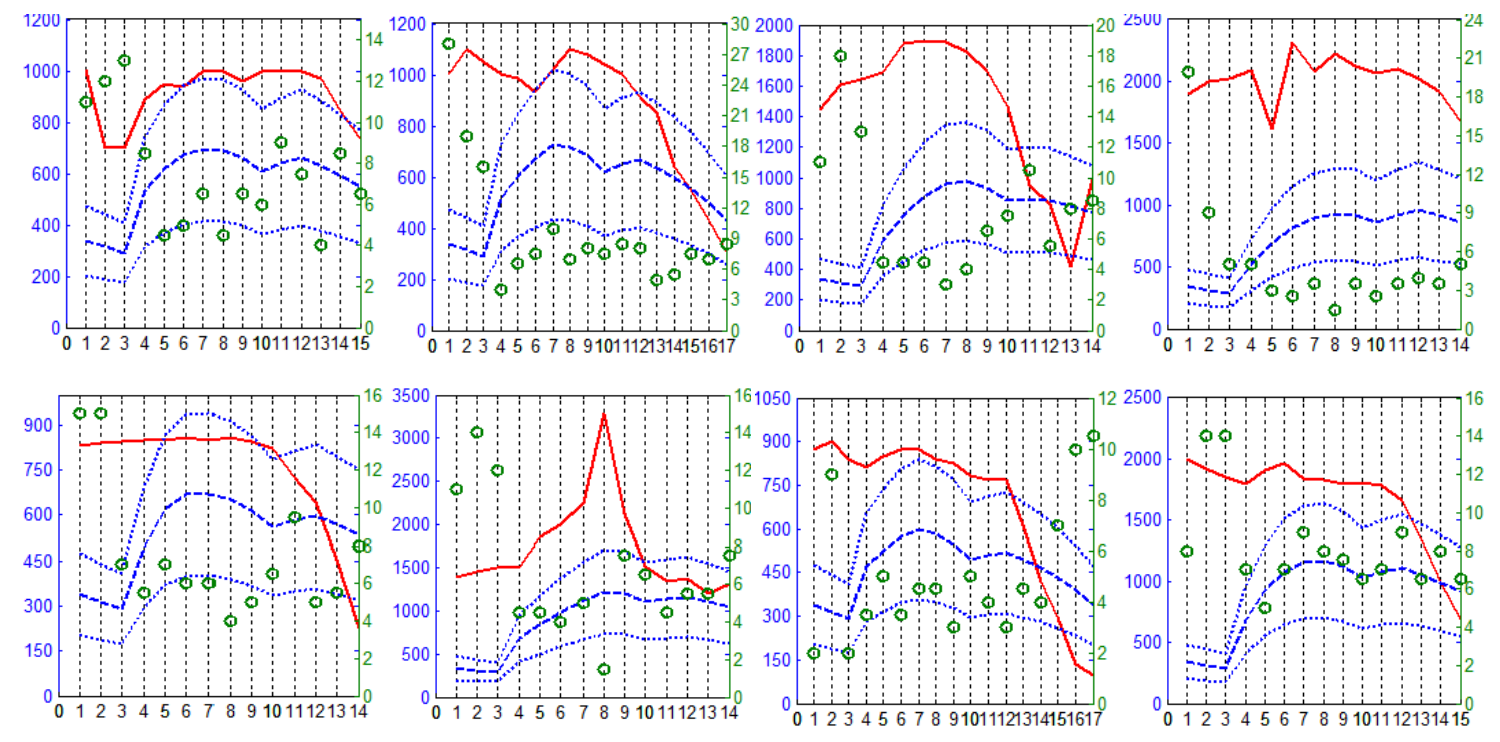

\section{Nolnstall}

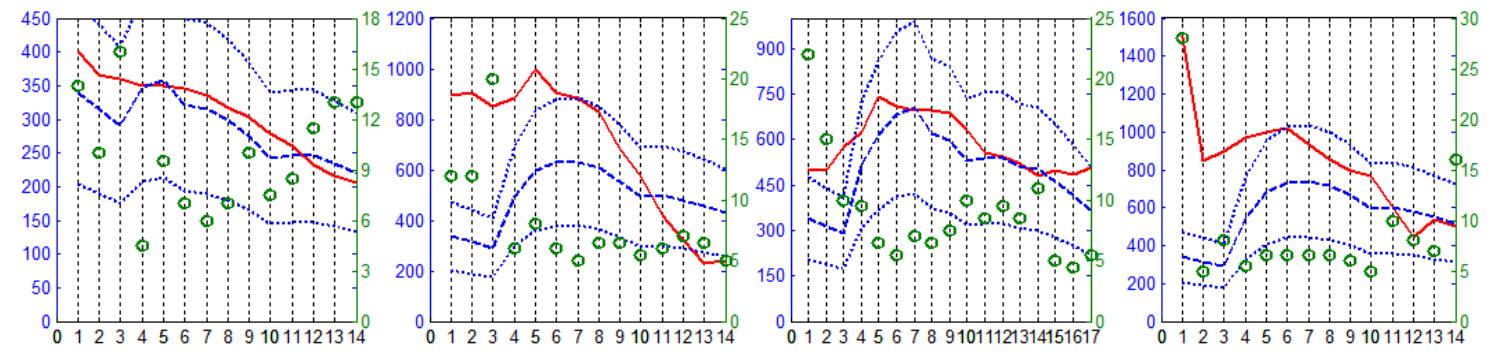

NoDefault

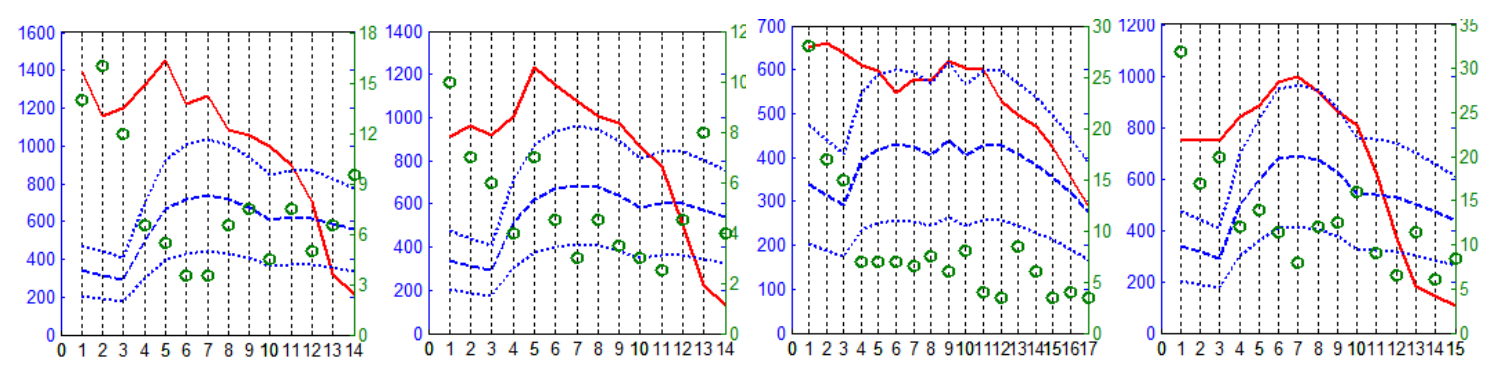

\section{NoSwap}

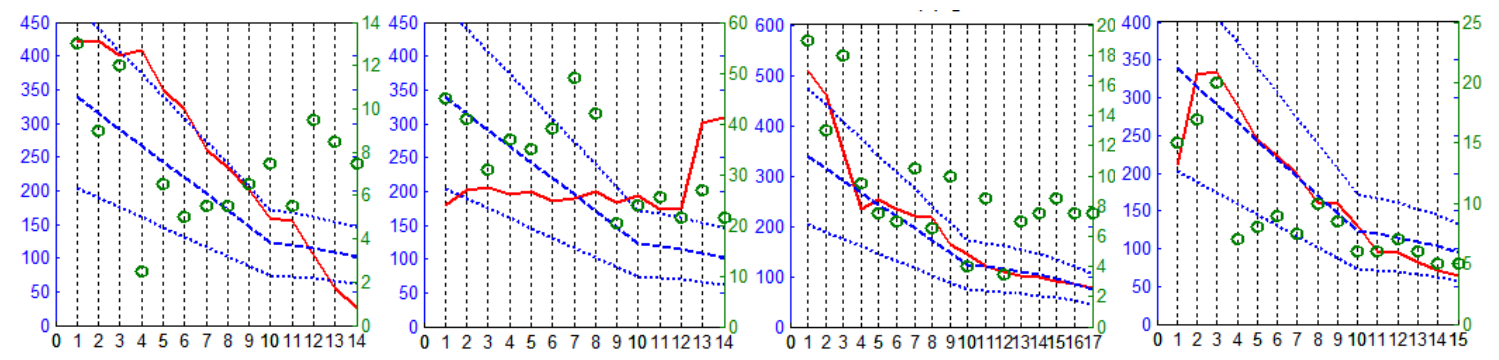


Figure 2. 1) First two rows: Baseline. 2) Third row: NoInstall. 3) Fourth row: NoDefault. 4) Fifth row: NoSwap. Graph legend: Left vertical axis: Price. Right vertical axis and green circles: number of trades. Horizontal axis: trading period. Red line: Average median trading price. Bold-dotted blue line: Fundamental value.

Figure 2 shows the time series of transaction prices for the second horizon of each session, as well as the time path of fundamental values. The fundamental value increases at the time of the first issue in all treatments except for NoSwap, since swapping debt for equity redistributes some of the new funds to existing shareholders as dividends. There is considerable heterogeneity between sessions within each treatment but, broadly speaking, they follow the basic overall patterns illustrated in figure 1.

In most sessions, after several new share issues, the price begins to decline. This decline typically begins at approximately periods $6-8$. In the four treatments other than NoSwap, prices exceed fundamentals by a considerable margin for an extended interval of time and in some sessions rapidly crash. In some sessions, the crashes are so severe that prices are below fundamentals at the time the market ends. This eventual drop in prices might be triggered by the impending end of the market by period 20 as well as the ever greater supply of units on the market. The increasing supply lowers the quantity of cash available for purchases relative to the quantity of asset available to purchase. Reductions in this ratio tend to lead to lower prices (Caginalp et al., 2000; Haruvy and Noussair, 2006).

To measure bubble magnitudes and compare them across treatments, we use the $\mathrm{RD}$ and RAD measures, as proposed in Stöckl et al. (2010). These are particularly well-suited for situations in which different markets in the dataset are characterized by differing numbers of periods and/or by different fundamental values, as they are in our study. This is because they normalize for average fundamental value and number of periods.

The relative absolute deviation, $\mathrm{RAD}=-\quad \longrightarrow$, measures the average level of mispricing compared to the average fundamental value of the market. The relative deviation, $\mathrm{RD}=-\quad-$, measures the extent of over or under-valuation. The values of RD and RAD observed in the second horizon of each session are indicated in table 4 , along with the treatment averages. 


\begin{tabular}{ccccc}
\hline \hline Treatment & Baseline & NoInstall & NoDefault & NoSwap \\
& 0.610 & 0.093 & 0.952 & 0.379 \\
& 0.608 & 0.602 & 0.758 & 0.422 \\
RAD & 1.069 & 0.170 & 0.425 & 0.181 \\
& 1.744 & 0.527 & 0.580 & 0.135 \\
& 0.511 & & & \\
& 0.917 & & & \\
& 0.627 & & & \\
\hline Average & 0.939 & & & \\
\hline Treatment & 0.878 & 0.348 & 0.679 & 0.279 \\
& Baseline & NoInstall & NoDefault & NoSwap \\
& 0.610 & 0.066 & 0.797 & 0.277 \\
& 0.568 & 0.410 & 0.533 & 0.049 \\
RD & 0.984 & 0.162 & 0.425 & 0.149 \\
& 1.744 & 0.483 & 0.291 & -0.057 \\
& 0.399 & & & \\
& 0.917 & & & \\
\hline \hline Average & 0.459 & & & 0.105 \\
\hline \hline
\end{tabular}

Table 4. RD and RAD for each session of each treatment (second horizon).

To investigate whether these differences are statistically significant, we run four (2-tailed) Mann-Whitney U-tests to test for differences in RA and RAD between Baseline and each of the other treatments. Table 5 reports the z-scores and the resulting significance level, for each pairing of treatments. The significant difference between the Baseline and NoSwap treatments provides the basis for our first result. 


\begin{tabular}{ccc}
\hline \hline & RAD & RD \\
Baseline & 0.878 & 0.823 \\
NoInstall & 0.348 & 0.28 \\
Z-Value & 2.378 & 2.208 \\
Significance & $2 \%$ & $3 \%$ \\
$\mathrm{~N}$ & 12 & 12 \\
\hline Baseline & 0.878 & 0.823 \\
NoDefault & 0.679 & 0.512 \\
Z-Value & 0.85 & 1.53 \\
Significance & $40 \%$ & $13 \%$ \\
$\mathrm{~N}$ & 12 & 12 \\
\hline Baseline & 0.878 & 0.823 \\
NoSwap & 0.279 & 0.105 \\
Z-Value & 2.717 & 2.717 \\
Significance & $<1 \%$ & $<1 \%$ \\
$\mathrm{~N}$ & 12 & 12 \\
\hline \hline
\end{tabular}

Table 5. Mann-Whitney-U-test of differences in RD and RAD between Baseline and each other treatment

Result 1: Redistributing revenues from new issues to existing shareholders increases bubble magnitude.

Support for result 1: Comparison of the Baseline and NoSwap treatments in table 5 indicates a strong and significant difference between the treatments. In all four sessions of the Baseline treatment, both RD and RAD are greater than in any session of the NoSwap treatment. The hypothesis that RD is equal in the two treatments, as well as the analogous hypothesis for RAD, is rejected at $\mathrm{p}<.01(\mathrm{z}-$ 2.717).

Figures 1 and 2 also indicate that prices are considerably lower in NoInstall than in the Baseline treatment. Result 2 is a statement that the difference is significant, and indicates that paying in installments does increase prices and bubble magnitude.

Result 2: Payment for new shares in installments increases prices and bubble magnitude. 
Support for result 2: In every session of the Baseline treatment, both RD and RAD are greater than in any session of the NoInstall treatment. Mann-Whitney tests indicate that the Baseline treatment has higher $\operatorname{RAD}(\mathrm{z}=2.378, \mathrm{p}=2 \%)$ and $\mathrm{RD}(\mathrm{z}=2.208, \mathrm{p}<3 \%)$ than the NoInstall treatment.

Finally, the possibility of defaulting on debt if the life of the asset ends does not have a significant effect on both bubble measures.

\section{Result 3: The ability to default on debts owed does not increase bubble magnitude.}

Support for result 3: When the Baseline treatment is compared with NoDefault, there is no significant difference neither in $\operatorname{RD}(z=1.53, p=13 \%)$ nor in $\operatorname{RAD}(z=$ $0.85, \mathrm{p}=40 \%)$.

In addition to comparing average prices, we can study the likelihood that a bubble forms. There is no consensus definition of a bubble, but the purposes of our experiment, we define a bubble as five consecutive periods during which the asset price remains more than a certain percentage above its fundamental value. That is, we say that a bubble occurs in a session if the session contains five consecutive periods in which median transaction prices exceed the fundamental by a threshold value. In table 6 we report the number of sessions with a bubble for threshold values of $30 \%, 40 \%$, and $50 \%$ of fundamentals.

\begin{tabular}{ccccc}
\hline \hline$\%$ & Baseline & NoInstall & NoDefault & NoSwap \\
$30 \%$ & 8 & 2 & 4 & 2 \\
$40 \%$ & 7 & 2 & 4 & 1 \\
$50 \%$ & 7 & 1 & 2 & 0 \\
\hline $\mathrm{N}$ & 8 & 4 & 4 & 4 \\
\hline \hline
\end{tabular}

Table 6. Number of sessions characterized by a bubble in each treatment.

Table 6 shows that the Baseline and NoDefault treatments produce bubbles in all sessions if the $30 \%$ criterion is used, and in at least $50 \%$ of sessions under the $50 \%$ criterion. NoInstall and NoSwap always generate fewer bubbles, independent of the cut-off used. Under the $50 \%$ criterion, the difference is particularly marked, with 7 sessions in the baseline showing bubbles - but only $1 / 2$ in the NoInstall/NoDefault treatments. NoSwap generates no bubbles at all under the $50 \%$ criterion. 


\section{IV.B Individual Behavior}

In this section we explore how the institutional factors that we have highlighted interact with trading strategies of individuals to either magnify or dampen bubbles. We employ the profile of trader types first proposed by Delong et al. (1990), and applied to experimental data by Haruvy and Noussair (2006) and Haruvy et al. (2013).

In this structure, there are three types of trader. (1) Fundamental Value Traders use the fundamental value as a limit price. They increase (decrease) share holdings when the current price is below (above) fundamental value. (2) Momentum Traders increase (decrease) share holdings in response to an upward (downward) price trend in the recent past. (3) Rational Speculators correctly anticipate the next period's price movement. If the price move is upward (downward), they increase (decrease) current holdings of shares.

We define an individual's behavior as consistent with the Fundamental Value Trader type in period $t$ if one of two conditions is met: Either (1) if $\left(\mathrm{p}_{\mathrm{t}}>\mathrm{f}_{\mathrm{t}}\right)$, then $\left(\mathrm{sit}_{\mathrm{it}}<\mathrm{si}_{\mathrm{i},-1}\right)$, or $(2)$ if $\left(\mathrm{p}_{\mathrm{t}}<\mathrm{f}_{\mathrm{t}}\right)$, then $\left(\mathrm{sit}_{\mathrm{it}}>\mathrm{si}_{\mathrm{i},-1}\right)$, holds. In conditions (1) and (2), $\mathrm{p}_{\mathrm{t}}$ is the average price in period $t, f_{t}$ is the fundamental value in period $t$, and $S_{i t}$ is the number of units of asset that individual i holds in period t. That, is the fundamental value trader purchases more shares than she sells in period $t$ if the price is below fundamentals, and sells more than she buys if the price is above fundamentals. A market populated predominantly with such types will tend to have prices that broadly track fundamental values.

Her behavior is consistent with the Momentum Trader type if either condition (3), if $\left(\mathrm{p}_{\mathrm{t}-1}<\mathrm{p}_{\mathrm{t}-2}\right)$, then $\left(\mathrm{Sit}_{\mathrm{t}}<\mathrm{S}_{\mathrm{i}, \mathrm{t},-1}\right)$ or $(4)$, if $\left(\mathrm{p}_{\mathrm{t}-1}>\mathrm{p}_{\mathrm{t}-2}\right)$, then $\left(\mathrm{sit}_{\mathrm{t}}>\mathrm{s}_{\mathrm{i},-1-1}\right)$, holds. The momentum trader accumulates units in period $t$ if there has been an increasing price trend between periods $t-2$ and $t-1$, or sells units if there has been a decreasing trend. These types generally do not contribute to pricing close to fundamentals. Indeed, they tend to generate momentum - they cause a continuation of previous trends, which can aid in inflating a bubble once it has begun.

A trader's behaviour is consistent with the Rational Speculator type if her behaviour in period $t$ satisfies one of the following conditions: (5) if $\left(\mathrm{p}_{\mathrm{t}+1}<\mathrm{p}_{\mathrm{t}}\right)$, then $\left(\mathrm{sit}_{\mathrm{i}}<\mathrm{Si}_{\mathrm{i},-1}\right)$, or $(6)$ if $\left(\mathrm{p}_{\mathrm{t}+1}>\mathrm{p}_{\mathrm{t}}\right)$, then $\left(\mathrm{sit}_{\mathrm{i}}>\mathrm{S}_{\mathrm{i}, t-1}\right)$. This type of agent anticipates the price in the next period in an unbiased manner. She makes positive net purchases if the price is about to increase between the current and the next 
period. She makes net sales if the price is about to decrease. These traders anticipate future trends and can initiate and sustain bubbles. When they expect prices to increase, they demand more shares, and thus their prediction becomes self-fulfilling.

We first assess each person's trading record in each period $t$, using the prices from periods $t-2$ and $t+1$ and the change in her holdings of asset, sit - sit,-1. We then classify her by the trading style with which she is consistent for the greatest number of periods. If there is a tie between two types, we classify the trader as belonging to each type with proportion 0.5 , and if there is a tie between all three types, he is assigned each type with proportion 0.33 .

As a measure of how much influence an individual exerts in her market, we use two variables. The first is a measure called Market Portfolio Influence.

The Market Influence of subject $i$ in period $t$ is defined as:

$=$

Where and indicate shares and cash owned by subject $i$ in period $t$, respectively while indicates the median transaction price for period $t$. The second is simply the share of the total outstanding shares that the individual holds, which is equal to $/ .^{17}$

Table 7 shows the average number of individuals in a market, classified as belonging to each of the three types, by treatment. The percentage of traders classified as each type is comparable in the four treatments.

\begin{tabular}{ccccc}
\hline \hline & Baseline & NoInstall & NoDefault & NoSwap \\
\hline & & & & \\
Momentum & 0.4 & 0.4 & 0.4 & 0.4 \\
Fundamental value & 0.3 & 0.4 & 0.3 & 0.5 \\
Rational speculator & 0.2 & 0.2 & 0.2 & 0.1 \\
\hline \hline
\end{tabular}

Table 7: Percentage of traders that are of each type, by treatment

\footnotetext{
${ }^{17}$ Haruvy and Noussair (2006) and Haruvy et al. (2013) use another measure of an individual's weight in the market, which they call Market Power. This is a weighted average of the percentage of the total cash, and the total stock of asset, in the market that an individual holds. The results reported in this section concerning Market Influence are very similar if Market Power is used instead as a measure of an individual's weight in the market. The market influence measure is an index of the current market value of a trader's position.
} 
The market influence of traders of each type is shown in figure 3. It reveals that the NoSwap treatment is the only one characterized by having Fundamental Value traders with more market influence on average than the other two types over the entire session. ${ }^{18}$ In each of the other treatments, Momentum traders have more market influence than the other two types for most of the trading session. In the Baseline treatment, momentum traders are dominant. NoDefault is similar in that momentum traders have the most influence throughout the trading session. In NoInstall, momentum traders have the most influence for most of the session, but fundamental value traders surpass them at the end. In NoSwap, fundamental value traders have the most weight among the three types at all times. Speculators have similar market influence in all of the treatments, except for NoSwap, where they have less.

Does looking at individual-level trading behavior shed light on the origins of the South Sea bubble? The debt-for-equity swap/new issuance of shares raised the fundamental value of shares. This increases the price Fundamental Value Traders are willing to pay, by a corresponding amount. Momentum traders, on the other hand, when observing any increase in price - whether justified or not increase their demand during subsequent periods. This tends to create and enhance bubbles. Speculators correctly anticipate this behavior of momentum traders (and in the case of new issuance, Fundamental value traders). They buy in advance of these investors, during the early stages of the price boom. The role of the debt swap is important according to the laboratory evidence because it causes an initial boost in fundamentals. The (appropriately) higher price then leads to reactions by momentum traders and speculating investors that magnifies the run-up in equity values, increasing the size of the bubble.

\footnotetext{
18 Periods 15-16-17 correspond only to one session per each treatment, and this accounts for the abrupt changes in period 15 in some of the panels of figure 3.
} 

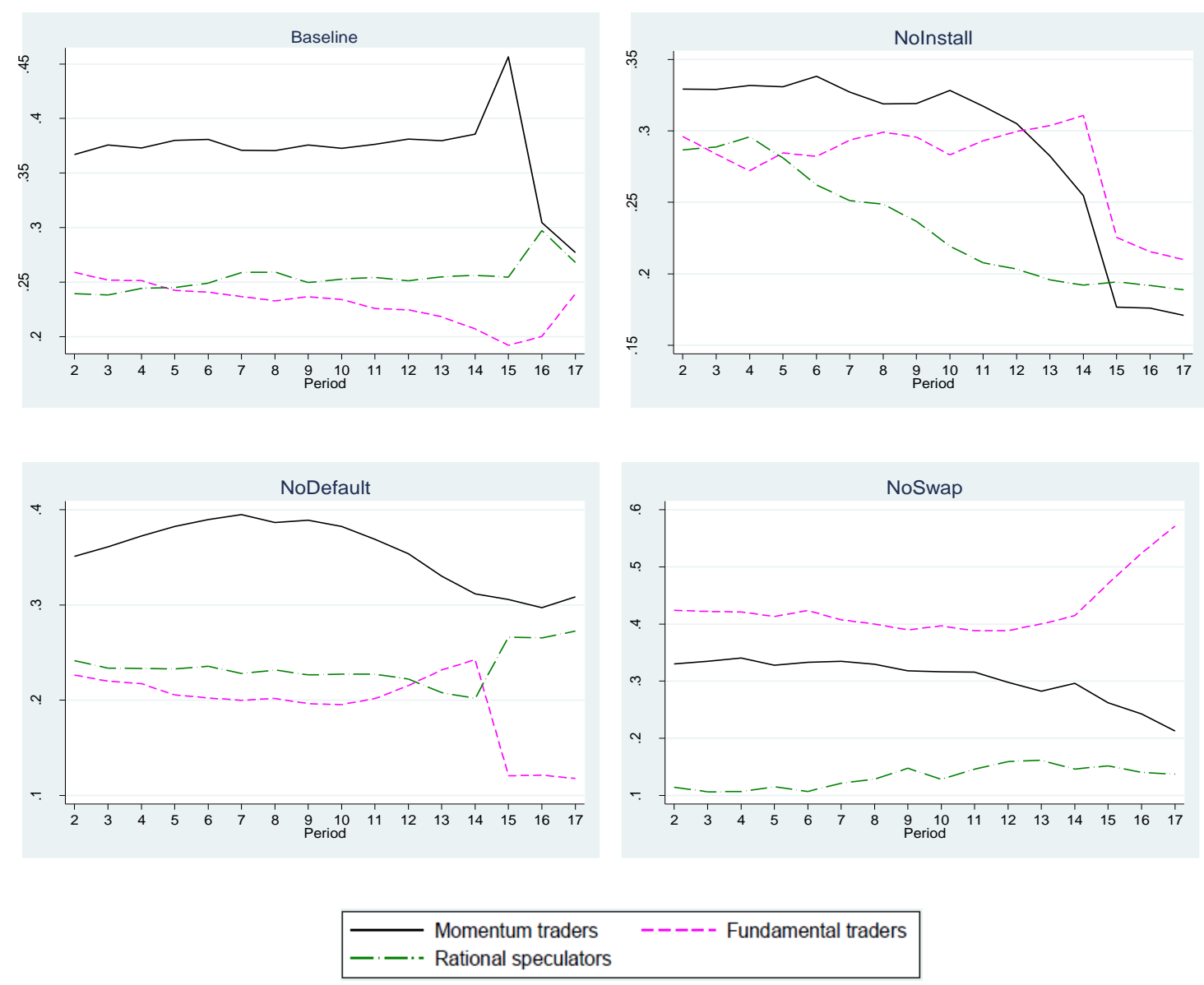

Figure 3. The market power for an individual of each trader type, averaged over all sessions of a treatment.

Table 6 illustrates how the proportion of units as well as the market power of each type depends on the asset's return in the preceding period. The independent variables are the return of the asset from the previous period to the current period. This is defined as:

Return $(t)=$

The second independent variable is the order of the new issue. This variable is equal to the number of issues that have occurred up to and including the current period. In the first two columns, the market influence and percentage of total shares held by rational speculators are the dependent variables. In the last four columns, the analogous variables for fundamental value and momentum traders are the dependent variables. 


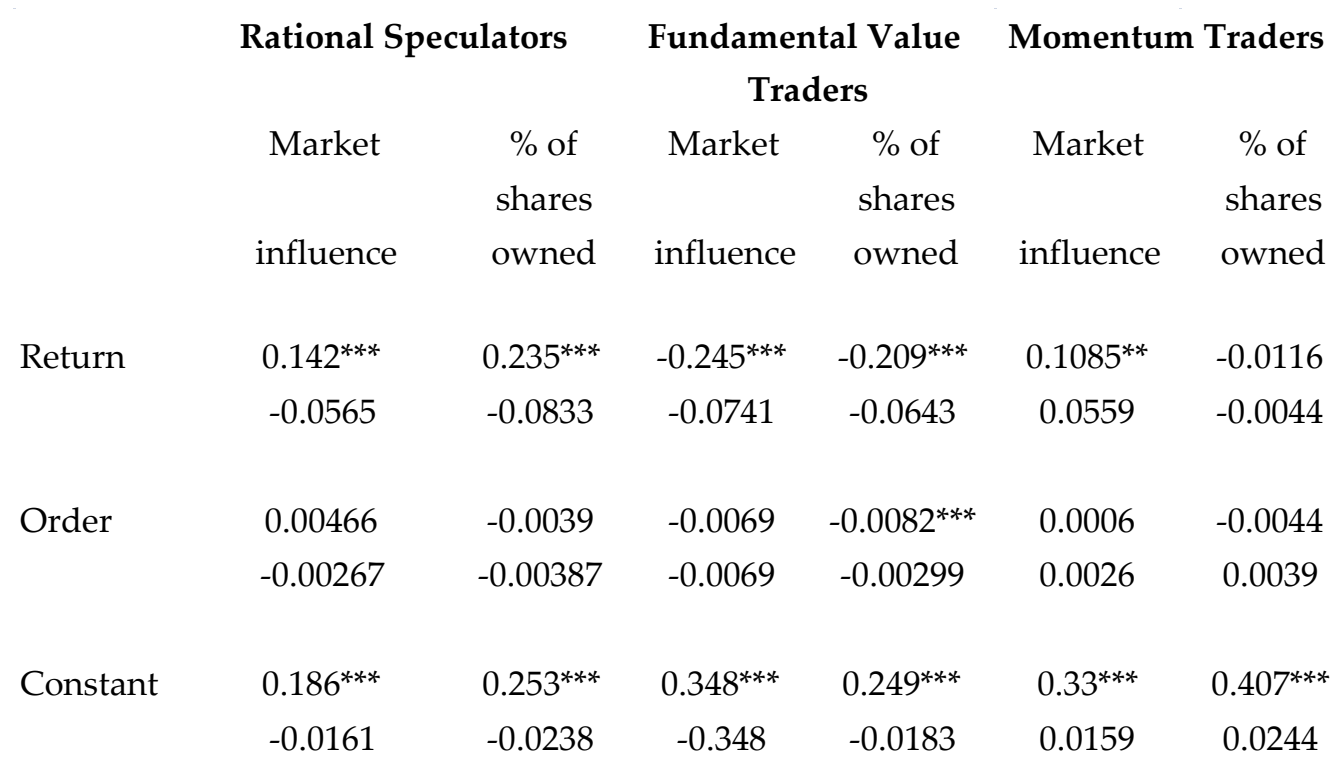

Observations $\quad 182$

Standard errors in parentheses; ${ }^{* * *} \mathrm{p}<0.01,{ }^{* *} \mathrm{p}<0.05,{ }^{*} \mathrm{p}<0.1$

Table 8. Market Influence and Quantity of Shares Held of Speculators, Momentum and Fundamental Value Types as a Function of Return and Number of Share Issues.

The estimates reveal several interesting patterns. High returns in the previous period attract purchases from rational speculators and momentum traders; they induce sales by fundamental value traders. These purchases increase the market influence of momentum and speculators and decrease those of fundamental value types. Low returns have the opposite effect, and induce the rational speculators to sell to fundamental value traders. The results for market influence imply that rational speculators on the whole are right in their prediction that past returns during our bubble experiment predict future returns. Fundamental traders, on the other hand, lose out - their influence decreases as they "lean against the bubble".

We also find an additional effect from share issuance. As more new issues come to the market, all else equal, fundamental value traders hold fewer units and exercise less market influence. This suggests that the degree of return predictability induced by the debt-for-equity swap weakened the influence of fundamental traders, creating opportunities for trend-chasing and for rational speculators. The data in table 7 and 8 are consistent with the following account of 
how new issues lead to a bubble. Momentum traders are typically the modal type of agent in our markets. If a new issue occurs, there is an immediate increase in fundamental value, and thus in the return on the asset. Fundamentaldriven investors bid up the price of the asset. In a market with many momentum traders, this price increase will continue for a while. This leads rational speculators to also make purchases, further driving up the price. Once prices get to be greater than fundamentals, it is the fundamental value traders who sell to speculators and to momentum traders. The price increase accelerates over time as more and more shares are issued since these are purchased by momentum traders and speculators. As Haruvy et al. (2013) argue, increases in the weight in the market of fundamental values are closely related to greater adherence of prices to fundamentals. The new issues serve to lower the market influence of fundamental value traders in the South Sea experiment because they create return predictability, drawing in momentum traders and rational speculators; this is ultimately the cause for the breakdown in the link between prices and intrinsic value. Under NoSwap, in which new issues have no effect on fundamental value, the process described here does not begin and prices remain close to fundamentals.

\section{Discussion}

The South Sea bubble and crash was one of the most spectacular episodes in financial history. Many idiosyncratic features of stock trading in the 1720s have been proposed as contributing to the bubble and crash, including corrupt allocation of shares to influential individuals, misleading information issued by the company about its prospects in the New World, and contagion from concurrent bubbles in Amsterdam and Paris. In this paper, we focus on specific institutional features of the asset market itself and analyse if these play a role in promoting bubble formation more generally. The use of laboratory experiments allows us to examine the impact of each aspect individually and in combination, allowing a precise determination of which market features promote instability the most.

Several historical features contribute to the formation of large bubbles in our experiments. At its core, the South Sea bubble is about a debt-for-equity swap, wherein the company offered to exchange government debt for its own shares (with the support of the UK government). At its peak, the South Sea company held 23\% of Britain's entire stock of public debt. The key manner in which this changed incentives to shareholders is that each issue of new shares meant that 
more interest payments were paid out to shareholders. In our NoSwap treatment, in which these payments did not occur, we observe no bubble. When no swapping of debt was possible, the other features that could enhance the formation of bubbles, risk shifting in the form of delayed payments for new shares, or the chance to default on these payments, did not generate a bubble.

In our experiments, we classify investors according to their predominant behavior into momentum traders, rational speculators, and fundamental-driven investors. Crucially, the swapping of equity for debt raised the fundamental value of shares for old owners. This meant that new subscriptions of shares raised the expected value of future dividends, and thus justified an increase in prices. An increasing price in turn attracted momentum investors and other speculators. Because these buy in parallel with the fundamental investors, prices increase and can exceed fundamentals for some time. The increase in fundamentals induced by particular contractual features of the 1720 debt swap is therefore crucial for the rapid rise in prices. In particular, the fact that the South Sea Company did not fix the "exchange rate" between stock and debt ex ante allowed it to buy out bond holders ever more cheaply (in terms of stock) as long as the price kept increasing. ${ }^{19}$

When there was swapping and new issuance took place, the ability to delay payment on newly-issued shares further increased the likelihood and magnitude of bubbles. The possibility of leverage increased the return to speculation in treatments with swapping because the swapping induced an increasing trend in prices. Without the establishment of an initial increasing price trend, the increased leverage did not enhance the returns to speculation.

More generally, a large literature has argued that bubbles are caused by initially fundamentals-driven, rational increases in share prices that become exaggerated through feedback loops in the market (Shiller, 2000) - such as in the case of electrification, the automobile, and aviation in the 1920s, or the internet in the 1990s. Our evidence about the importance of the debt-equity swap, which boosted the intrinsic value of South Sea stock, appears to be in line with this interpretation. Note also that the laboratory findings coincide precisely with Charles Kindleberger's (1987) classic definition of the origins of a bubble:

\footnotetext{
${ }^{19}$ Interestingly, this feature was not present in 1719, when the South Sea Company swapped its shares for so-called "lottery tickets", another kind of government debt (Carswell 1960). Then, there was also no explosion in share prices.
} 
"A bubble may be defined loosely as a sharp rise in price of an asset ..., with the initial rise generating expectations of further rises and attracting new buyers-generally speculators interested in profits from trading rather than in its use or earning capacity."

Overall, the experimental evidence lends support to classes of bubble models emphasizing investor heterogeneity. For example, in Hong, Sheinkman, and Xiong (2006), investors receive different signals about the fundamentals of an asset. Bubbles can form because the resale (option) value to the other group induces even those who are pessimistic about fundamentals to buy. This is similar to the interaction between fundamental-driven investors, rational speculators, and momentum traders in our experiment, which requires an increase in fundamental value, resulting from the debt-equity swap, to ignite a major speculative frenzy. 


\section{References}

Allen, Franklin, and Douglas Gale. 2000. "Bubbles and Crises." The Economic Journal 110 (460): 236-255.

Alsemgeest, Paul, Charles Noussair, and Mark Olson. 1998. "Experimental Comparisons of Auctions Under Single-and Multi-Unit Demand." Economic Inquiry 36 (1): 87-97.

Breaban, Adriana and Charles Noussair. 2013. "Fundamental Value Time Paths and Pricing in Experimental Asset Markets", working paper, Tilburg University.

Brunnermeier, Markus K., and Stefan Nagel. 2004. "Hedge Funds and the Technology Bubble." The Journal of Finance 59 (5) (October 1): 2013-2040.

Carswell, John. 1960. The South Sea Bubble. Cresset Press.

- - - . 1993. The South Sea Bubble. Alan Sutton.

Corgnet, B., R. H. Gonzalaz, P. Kujal and D. Porter (2012), "The Effect of Earned vs. House Money on Price Bubble Formation in Experimental Asset Markets", working paper, Chapman University.

Dale, Richard. 2004. The First Crash: Lessons from the South Sea Bubble. Princeton University Press.

Dale, Richard S, Johnnie EV Johnson, and Leilei Tang. 2005. “Financial Markets Can Go Mad: Evidence of Irrational Behaviour During the South Sea Bubble1." The Economic History Review 58 (2): 233-271.

Easley, David, and Maureen O'hara. 2004. "Information and the Cost of Capital." The Journal of Finance 59 (4): 1553-1583.

Fama, Eugene. 1965. “The Behavior of Stock-market Prices.” Journal of Business: 34-105.

Fischbacher, Urs. 2007. "z-Tree: Zurich Toolbox for Ready-made Economic Experiments." Experimental Economics 10(2): 171-178.

Fisher, Eric O’N., and Frank S. Kelly. 2000. “Experimental Foreign Exchange Markets." Pacific Economic Review 5 (3): 365-387.

Frechette, Guillaume. 2009. "Laboratory Experiments: Students vs. Professionals", working paper, New York University.

Garber, Peter M. 2001. Famous First Bubbles: The Fundamentals of Early Manias. Reprint. The MIT Press.

Greenwood, Robin, and Stefan Nagel. 2009. "Inexperienced Investors and Bubbles." Journal of Financial Economics 93 (2): 239-258.

Harris, Ron. 1994. "The Bubble Act: Its Passage and Its Effects on Business Organization." The Journal of Economic History 54 (3) (September 1): 610627. 
Haruvy, Ernan, and Charles N. Noussair. 2006. "The Effect of Short Selling on Bubbles and Crashes in Experimental Spot Asset Markets." Journal of Finance 61 (3): 1119-1157.

Haruvy, Ernan, Charles N. Noussair, and Owen Powell. 2013. "The Impact of Asset Repurchases and Issues in an Experimental Market." Review of Finance (April 6).

Hong, Harrison, José Scheinkman, and Wei Xiong. 2006. "Asset Float and Speculative Bubbles." The Journal of Finance 61 (3): 1073-1117.

Hutcheson, A. 1720. Collection of Calculations and Remarks Relating to the South Sea Scheme. London.

Kaul, Aditya, Vikas Mehrotra, and Randall Morck. 2000. “Demand Curves for Stocks 'Do' Slope Down: New Evidence from an Index Weights Adjustment." Journal of Finance 55 (2): 893-912.

Lintner, John. 1971. "The Effect of Short Selling and Margin Requirements in Perfect Capital Markets." The Journal of Financial and Quantitative Analysis 6 (5) (December 1): 1173-1195.

Long, J. Bradford de, Andrei Shleifer, Lawrence H. Summers, and Robert J. Waldmann. 1990. "Positive Feedback Investment Strategies and Destabilizing Rational Speculation." The Journal of Finance 45 (2) (June 1): 379-395.

Lynch, A.W, and R.R Mendenhall. 1997. "New Evidence on Stock Price Effects Associated with Changes in the S\&P 500 Index." Journal of Business 70 (3): 351-383.

Neal, Larry. "I Am Not Master of Events": The Speculations of John Law and Lord Londonderry in the Mississippi and South Sea Bubbles. Yale University Press, 2012.

Mikkelson, W., and M. Partch. 1985. "Stock Price Effects and Costs of Secondary Distributions." Journal of Financial Economics 14: 165-194.

Palan, Stefan. 2013. "A Review of Bubbles and Crashes in Experimental Asset Markets." Journal of Economic Surveys

Shea, Gary S. 2007. "Financial Market Analysis Can Go Mad (in the Search for Irrational Behaviour During the South Sea Bubble) -super-1." Economic History Review 60 (4): 742-765.

Shleifer, Andrei. 1986. “Do Demand Curves for Stocks Slope Down?" The Journal of Finance 41 (3): 579-590.

Smith, Vernon L. 1962. "An Experimental Study of Competitive Market Behavior." Journal of Political Economy 70.

Smith, Vernon L., Gerry L. Suchanek, and Arlington W. Williams. 1988. "Bubbles, Crashes, and Endogenous Expectations in Experimental Spot Asset Markets." Econometrica 56 (5) (September 1): 1119-1151. 
Stöckl, Thomas, Jürgen Huber, and Michael Kirchler. 2010. "Bubble Measures in Experimental Asset Markets." Experimental Economics 13 (3) (September 1): 284-298.

Temin, Peter, and Hans-Joachim Voth. 2004. "Riding the South Sea Bubble." American Economic Review 94 (5) (December): 1654-1668.

- - - 2013. Prometheus Shackled: Goldsmith Banks and England's Financial Revolution after 1700. Oxford University Press, USA.

Wurgler, Jeffrey, and Ekaterina Zhuravskaya. 2002. "Does Arbitrage Flatten Demand Curves for Stocks?" The Journal of Business 75 (4): 583-608.

\section{Online Appendix}

\section{Baseline treatment instruction.}

You are taking part in an experiment on decision making. The instructions are simple and if you follow them carefully and make good decisions, you can earn some money, which will be paid to you at the end of the experiment.

The experiment consists of a sequence of trading periods, each one lasting 150 seconds. During each period, you will have the opportunity to buy and sell units of two assets of an imaginary Company named "Blue River" in a market. The first asset is called "Share A" while the second is called "Share B". During the instructions we will explain differences between them. The currency used in this experiment is called ducats, which will be converted into Euros at the end of the experiment at an exchange rate of $\mathrm{xx}$ DUCATS for 1 Euro. You will have to participate in two separate markets. At the end of the experiment one market is randomly selected and your payment will correspond to this selection.

\section{How to buy and sell shares}

We will first explain how the market works, and then you will have time to practice trading. If anything is unclear at any time, you can raise your hand and ask the experimenter any question you may have. 


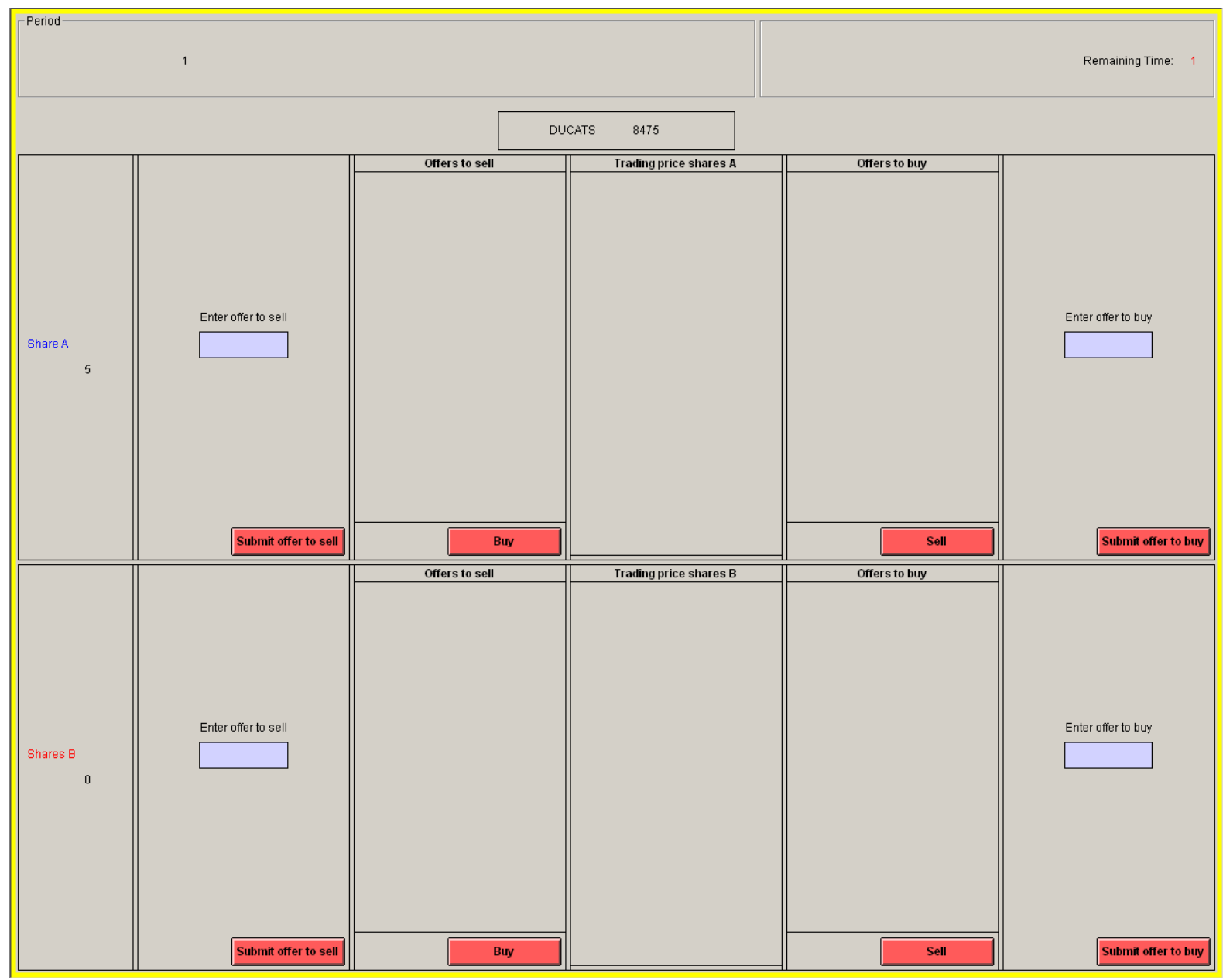

This is the trading screen you will use during the experiment.

You start the experiment with a quantity of money called "DUCATS" and a number of shares "A". You will not start with any share "B".

We will explain how trade occurs in the market for "Share A", which occurs exactly in the same way as for "Share B".

The top left corner shows the current trading period, and the top right corner shows how much time (in seconds) is left in the current period. Your ducat balance is shown in the middle of the screen. Using this screen, you can buy or sell shares in four ways.

First, you can initiate a sale of shares by submitting an offer to sell.

If you have shares, you may choose to sell them. You can initiate a sale in the text area below "Enter offer to sell" in the first column. Here you can enter the price at which you are offering to sell a share. To send the offer, you have to click the 
"Submit offer to sell" button. After that, your offer to sell will appear in the second column labelled "Offers to sell". Each offer introduced corresponds to one single share. If you want to sell more shares, repeat this process.

Note that by submitting an offer to sell, you initiate a sale, but the sale will not be executed until someone accepts it.

Try offering to sell a share now. Enter a number in the text area labelled "Enter offer to sell" in the market for "Shares A" and then click on the button "Submit offer to sell". You can see that a set of numbers will appear in the column labelled "Offers to sell". Each number corresponds to an offer from one of the participants. Your own offers are shown in blue; others' offers are shown in black. The offers to sell are ranked from high to low, so that the cheapest (best) price is displayed at the bottom of the list.

Second, you can buy shares by accepting an offer to sell.

If you have enough ducats, you can buy a share at one of the prices in the "Offers to sell" column (which also contains your previously submitted offer to sell). You buy a share by selecting one of the others' offers (shown in black) and then clicking on the red button "Buy". Note that you are not allowed to accept your own offers, which are shown in blue. Remember that the cheapest (best) price is displayed at the bottom of the list.

It may happen that when you select the best price and press the "Buy" button, someone else is doing the same thing but acting faster than you. In that case, a message "someone has been faster than you" or "you have to select a price" will appear.

Try buying a share now. Choose a price in the "Offer to sell" column and then click on the "Buy" button, or click directly on the "Buy" button and buy at the cheapest price listed in the "Offers to sell" column.

Whenever an offer is accepted, a trade occurs. When you accept an offer to sell, you realize a purchase and the number of ducats in your ducat balance goes down by the transaction price; at the same time, your trading partner makes a sale and his/her ducat balance increases by the trading price. In contrast, when your offer to sell is accepted, you make a sale, your trading partner makes a purchase, and an amount of money is transferred from your trading partner to you that is equal to the amount of the trading price. 
Because you have each submitted one offer to sell and accepted one offer to sell, you have all realized one purchase and one sale so that you have the same number of shares as you started out with.

Third, you can initiate a purchase of a share by submitting an offer to buy.

If you have ducats and would like to buy a share, you can initiate the purchase by submitting an offer to buy. Enter a number in the text box under "Enter offer to buy" situated on the right side of the screen and then click on the "Submit offer to buy" button.

Try submitting an offer to buy a share now. Enter a number in the text area "Enter offer to buy" in the market for "Shares A" Then press the red button labelled "Submit offer to buy". Immediately, in the column labelled "Offers to buy", you will see a list of numbers ranked from low to high, so that the highest (best) price is displayed at the bottom of the list. If you want to sell more shares, repeat this process. Again, your own offers are shown in blue; others' offers are shown in black.

Fourth, you can sell a share by accepting an offer to buy.

You can sell a share at one of the prices offered in the "Offers to buy" column (which also contains your previously submitted offer to buy). Select one of the offers and then click on the red button "Sell". Again, note you are not allowed to accept your own offers (shown in blue). Remember that the highest (best) price is displayed at the bottom of the list.

Try selling a share now. Choose a price in the column "Offer to buy" and then click on the "Sell" button.

A transaction occurs whenever an offer to buy is accepted. If you accept an offer to buy posted by another person, you make a sale and as a result, the amount of ducats you have increases by the trading price. In contrast, when your offer to buy is accepted by someone else, you realize a purchase and the number of ducats you have decreases by the trading price. The opposite happens to your trading partner.

You can see that these four trading methods are complementary: you can initiate a trade by offering a price to sell or buy and wait for the offer to be accepted by others; you can execute a trade by accepting an offer to buy or sell submitted by another participant. 
In the column situated in the middle of the screen and labelled "Trading price", you can see the prices at which shares have been traded during the trading period by all participants playing in the market.

\section{Information display at the end of each period}

At the end of each trading period a screen appears that summarizes your situation.

"End-of- period screen"

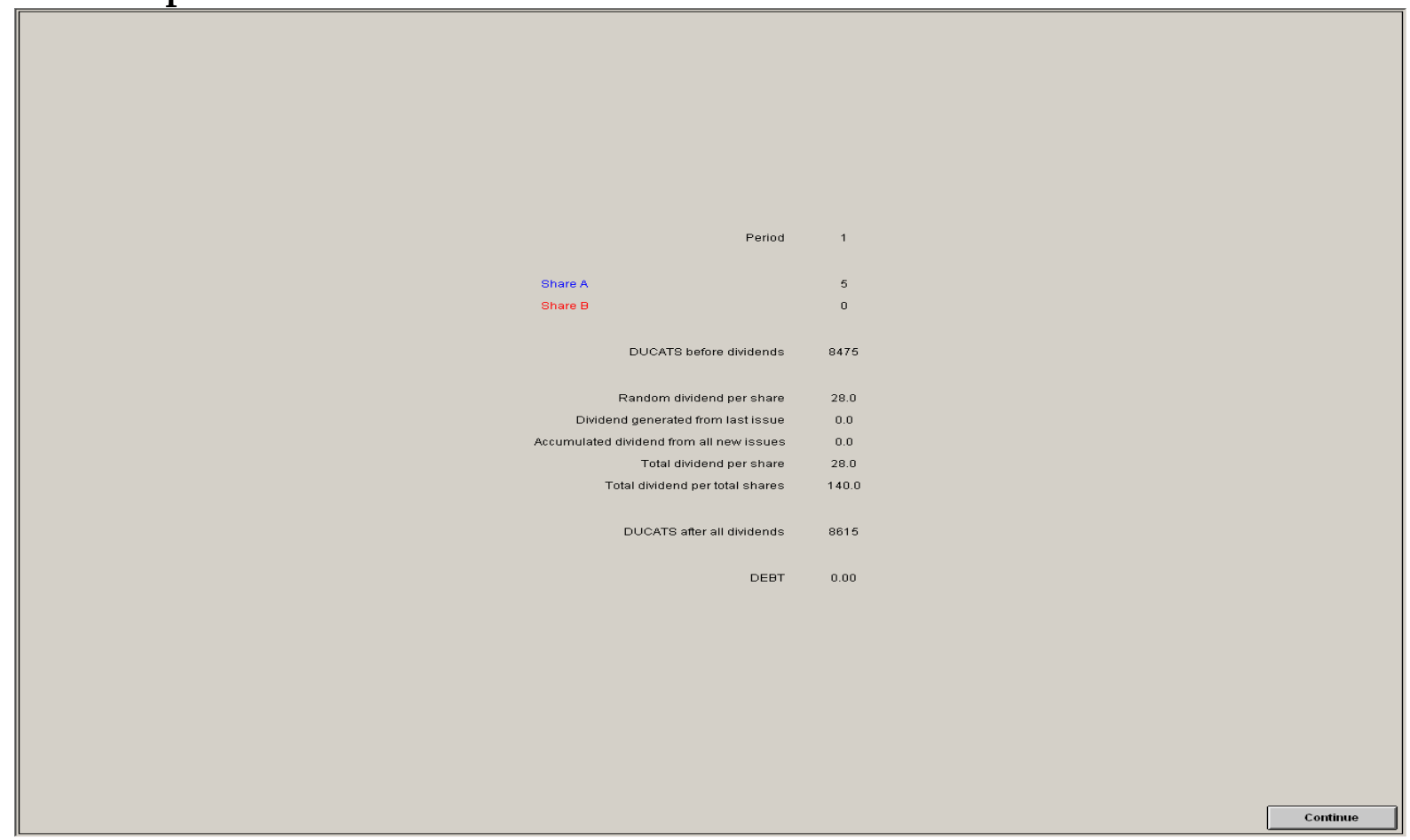

In this screen you have the following information:

A) Period: This is the trading period just finished.

B) SHARE A: The number of shares of type " $\mathrm{A}$ " you own at the end of this period.

C) SHARE B: The number of shares of type "B" you own at the end of this period.

D) DUCATS before dividends (dividends will be explained later): This is the money you have before you receive the current period's dividend payment. 
E) Random dividend per share: As explained later, each share you own may pay a dividend at the end of each trading period. The random dividend per share is the amount in ducats you get in this trading period for each share you own.

F) Dividend generated from last issue: Share issues, in which the experimenter makes new B shares available, will be described later in the instructions. Each time that new shares are issued on the market, the dividend you receive on both shares A and B increases. This dividend generated from last issue is the increase in dividend that results, from the last issue of shares only. If no shares are issued it is equal to 0 .

G) Accumulated dividend from all new issues: As will be explained later, during the experiment new shares may be issued. Each time that new shares arrive on the market, if you decide to buy them, the amount of dividend you receive on the shares that you own increases. The Accumulated dividend from all new issues is the total of all dividends derived from all new issues of shares.

H) Total dividend per share: This is the sum of E + G.

I) Total dividend $x$ total share: This is the total dividend per share $[\mathrm{H}]$ times the number of shares (shares $A+$ shares B) you own since each share " $A$ " and "B" receives the same dividend per period.

L) Ducats after all dividends: This is the sum of total dividend $x$ total shares plus your Ducats before dividend. (D+I).

M) Debt: This will be explained later.

\section{Random Dividend}

For each share you own of both type of shares " $A$ " and "B" you receive a dividend at the end of each trading period. A random device determines the dividend you get for the period for each share you own.

The amount and the chance of each possible dividend are the following: 
$25 \%$ chance you get 0 ducats per share you own

$25 \%$ chance you get 8 ducats per share you own

$25 \%$ chance you get 28 ducats per share you own

$25 \%$ chance you get 60 ducats per share you own

Each participant gets the same dividend per share at the end of the period. The average dividend in a period is equal to 24 ducats. This is calculated as following: $(0+8+28+60) / 4=24$. The dividends that were drawn in earlier periods do not influence the chance of getting a given dividend this period; in other words, if dividends were high in earlier periods, it doesn't mean that they are more or less likely to be high or low this period than if previous dividends had been low.

\section{How long the market lasts}

The market lasts for a minimum of 10 and a maximum of 20 trading periods, each period lasting 150 seconds. In each of the periods between 10 and 20 the experiment could end. Whether it ends or not is determined with a random device. Beginning in period 10, at the end of every period there is:

an $83 \%$ chance that the market continues to the next period, and a $17 \%$ chance that the market ends immediately.

This means that dividends from period 10 onward are not guaranteed because the market might end.

\section{Your average holding value table}

Your "Average holding value" table indicates the total of the dividends you would get on average if you held a share from any period until the market ends, if there are no new shares issued (i.e. subscribed) you can use this table to help you make decisions.

Average holding value table 


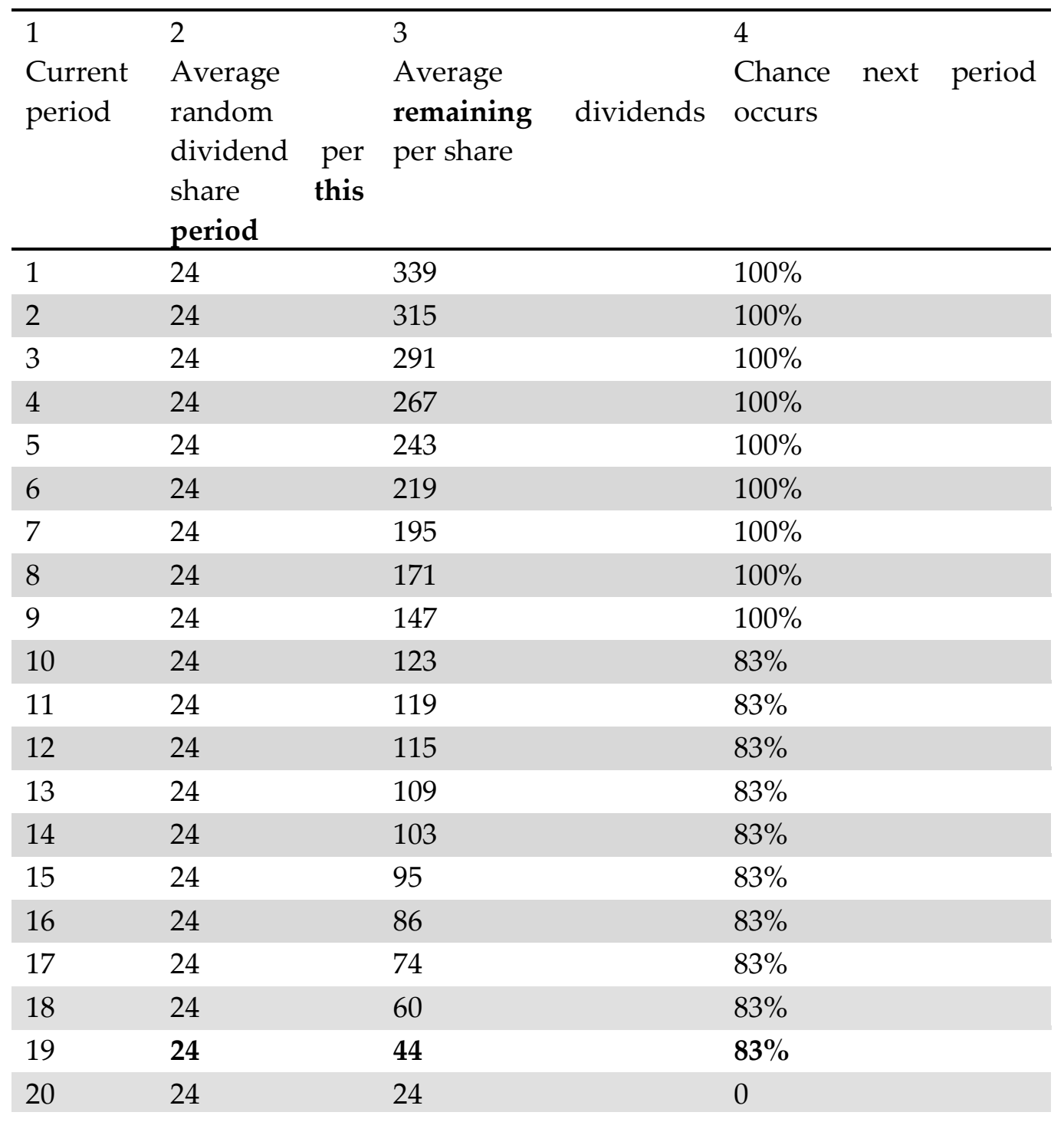

The columns in the table refer to the following:

Current period: The period corresponding to the number in the row. For instance for period 2 you would receive on average total future dividends of 315 for each share you held until the end of the market in case there are NO issues of new shares.

Average random dividend per share this period: The average amount of dividend per period for each share you own. This is equal to 24 in each period as explained above. 
Average remaining dividends per share: The average amount of total dividend you will receive for each share that you own from now until the end of the experiment. It is the average amount of dividend ( 24 ducats) multiplied by the average remaining number of periods. From period 11 on, there is an $83 \%$ chance that the market will continue for another period. The calculation of the average remaining dividends takes this into account. For instance if you are currently in period 5, the average expected dividend you would get from owning one share until the end of the experiment is 243 .

Chance next period occurs: The probability that the following period exists.

\section{Issues of type " $B$ " Shares}

Beginning in period 3 you might have the opportunity to buy additional shares of type " $\mathrm{B}$ " from the experimenter. Type B shares pay the same dividends as type A shares and can be bought and sold in the same way as A shares. B shares are issued in some rounds for a price determined in an auction, which is described below. However, you will not be informed in advance about the total number of times or in which periods B shares will be issued.

If an issuing round takes place (i.e. a screen like this appears), you have to participate to an auction. 
Suscription of Shares "B"

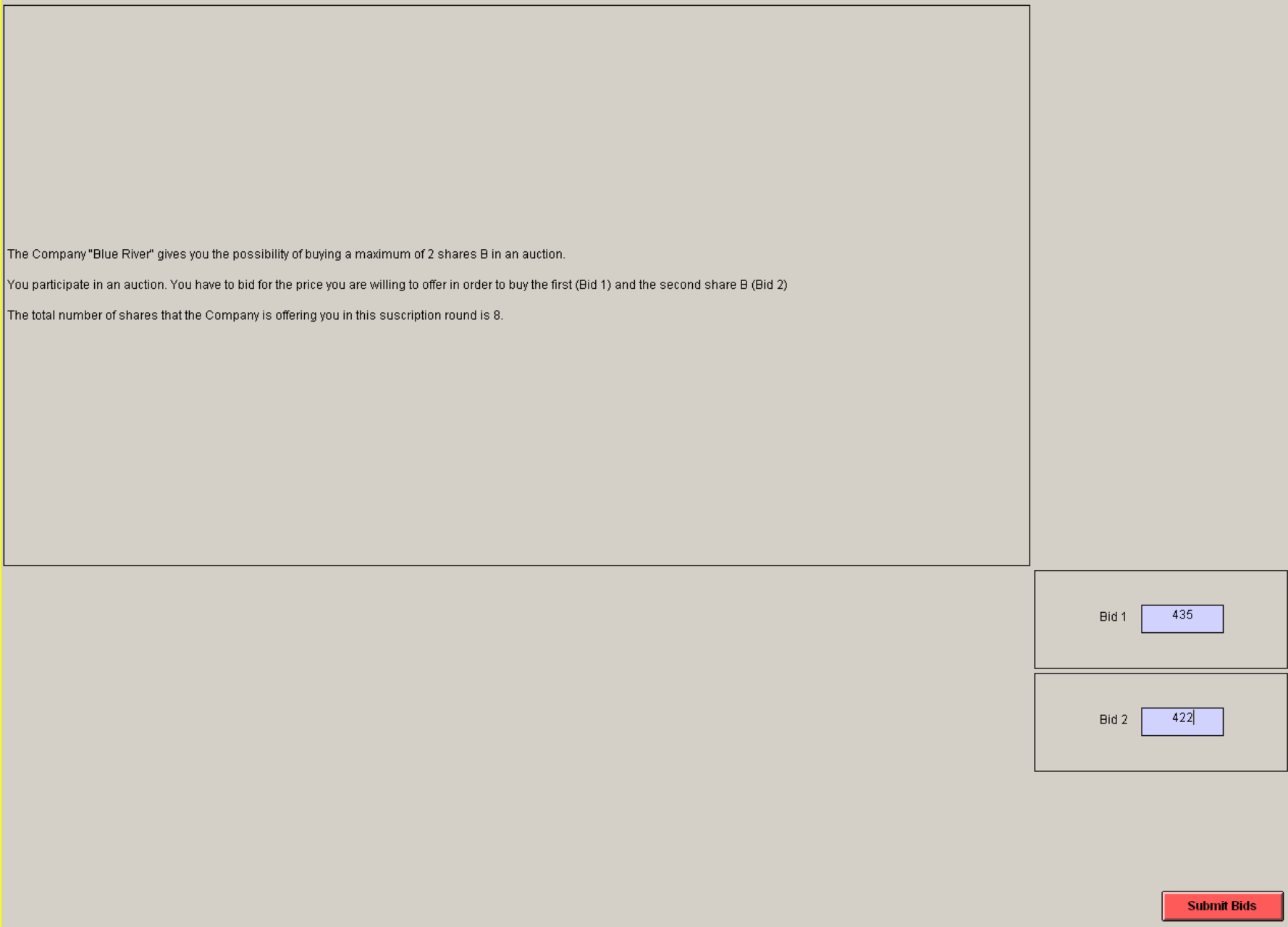

Screen 3. Auction

You can make bids on up to $2 \mathrm{~B}$ shares.

You must bid on two shares. If you do not want to buy a share, you can type in a bid of 0 in both spaces. If you are sure that you don't want to buy any more than 1 unit, you can type 0 in the box labeled "Bid 2" and enter the bid for the one unit you are interested in bidding for in the box labeled "Bid 1"

Once you and the other participants have submitted their bids, by clicking on the "submit bids" button, a new screen appears. It looks like the one shown below 


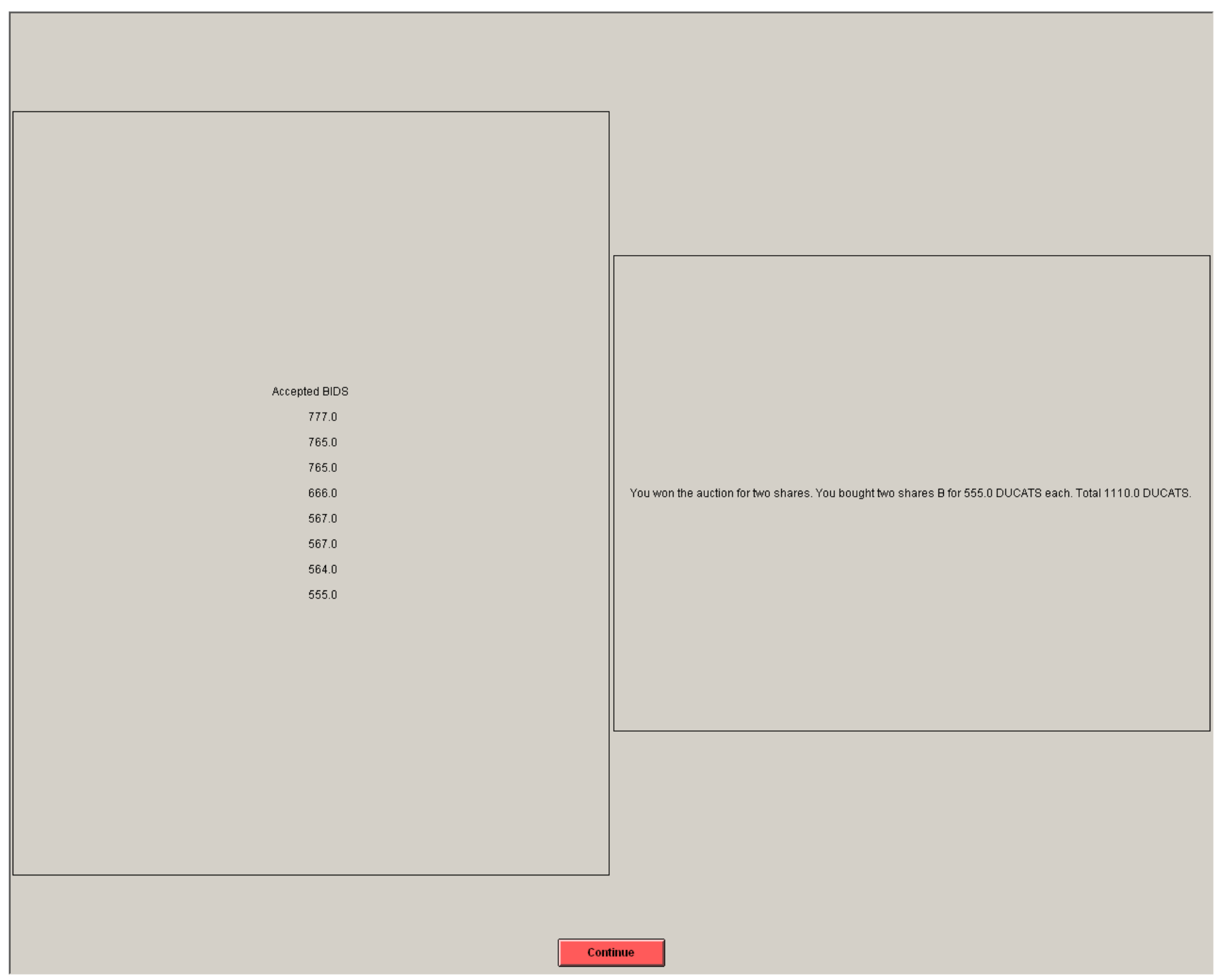

On this screen you can see the accepted bids from all participants in the market, ranked in order of how large they are. The people who sent in these accepted bids receive a unit for each bid they have accepted. If you have one bid on the list, you get 1 unit, and if you have 2 bids on the list you get two units.

The last price on this list, which is the lowest accepted bid, is the amount of Ducats that you will have to pay for each of your bids on the list.

On the right corner of the screen you can see whether you purchased one or two newly issued shares $B$, and the price you pay for each share.

If you purchase newly issued shares " $\mathrm{B}$ ", the experimenter lends you some of the money to buy them. This means that you do not have to have enough ducats on 
hand at the moment to buy the shares, because you pay most of what you owe for the shares later on.

In the period where you buy the newly-issued B shares from the experimenter, you pay $20 \%$ of the auction price. The remaining $80 \%$ are debt that you owe to the experimenter. In each of the following 4 periods, $20 \%$ of the price will be subtracted from your ducat balance. Your debt is therefore paid off over 5 periods. The amount of debt that you have at any time will be reported on your "After period screen" after each period in the field labeled DEBT.

If the market ends before you pay back your debt, you do not have to pay back your remaining debt.

For example. Suppose that there are two issues of shares "B", one in period 4 and one in period 12. Suppose that the game ends after period 13, and that the issued price of each share was of 300 . You purchased one B share in period 4 and one in period 12.

In period 8 , you will have fully repaid your debt on the first share $(20 \%$ in period 4 and $20 \%$ in each of the following four periods).

In period 13, when the market ends, you will have paid back 120 ducats on the share you purchased in period 12 . The 120 is equals to $20 \%$ of the 300 plus the $20 \%$ of the 300 of period 12 and 13 respectively. If the market ends and you still owe debt (as it is the case in this hypothetical example), you do not have to repay it.

Notice that after the unit has been purchased in the auction, $\mathrm{A}$ and $\mathrm{B}$ shares are the same from the point of view of any new buyer. The two types of share pay the same dividends in each period, and the two types of shares will continue to exist until the game ends. Because the two types of share are the same, an individual can make a profit if she can sell one at a higher price and buy the other at a lower price. This is because the asset she bought and the asset she sold will always pay the same dividends and she has more cash than he did before. For example, suppose that you sell an A share at 300 Ducats and you purchase a B share at 200 Ducats five seconds later. You then have the same number of shares as before, but have 100 Ducats more than before, so you have made a profit of 100 Ducats. 


\section{Increasing in the amount of dividend received.}

The number of issues is unknown. Each time that you subscribe to new shares B, "Blue River Company" is using the collected money to buy investment certificates in a secondary market. The higher the price at which Blue River shares are issued, and the more buyers there are for these new shares, the more of these investment certificates can be bought. The dividends from these certificates will be added to the ones paid out by Blue River on share A and B.

For example: suppose that in period 10 the Company offers the possibility of buying new shares B. Therefore you participate in an auction. Imagine that the result of the auction is that the price for one share B is 320 ducats each. If all of you in total have bought 8 shares, Blue River will gather 2560 ducats $(320 * 8)$.

With this money the Company buys 25.6 certificates (2560 ducats/100). Each certificate pays a dividend of 15 ducats. Therefore a total of 384 ducats will be divided for the total number of shares outstanding in the market and paid to each of you as dividends after each market.

This means that if in the market there is a total of 30 shares (22 initials and 8 new issued), you receive additionally to the random dividend (explained in the instructions) a new increment of 12.8 ducats for each share you own (384/30).

This means that the value of owning both $A$ and $B$ shares increases as the total number of $\mathrm{B}$ shares in the market increases.

If B shares are issued, the numbers "Average remaining dividend per share" column will change. For example, after a single issuing round of shares " $\mathrm{B}$ ", in period 4, for a price of 320 ducats (the same example as above), the "Average remaining dividend per share" column of the row 4 will change from 267 ducats to 351 ducats. The entire column will change automatically, and the average remaining dividends will be increased again each time new shares are bought.

A table called "Average remaining dividends per share" will be displayed at the end of each period. This table is the current updated version of the "Average holding value table" described earlier and should be read exactly in the same way. You might want to use the information in the table to see how "Average remaining dividends" are updated after each issuing round.

In the screenshot shown here you can see how "average remaining dividends per share" has been affected after a single share issue and compare it with the "Average holding value table" above. In the example reported below, at the end of period 3 there was an issue of shares and all values in the "Average remaining 
dividends" column for future periods increased substantially compared to the original "Average holding table" 


\section{Updated "Average holding value table"}

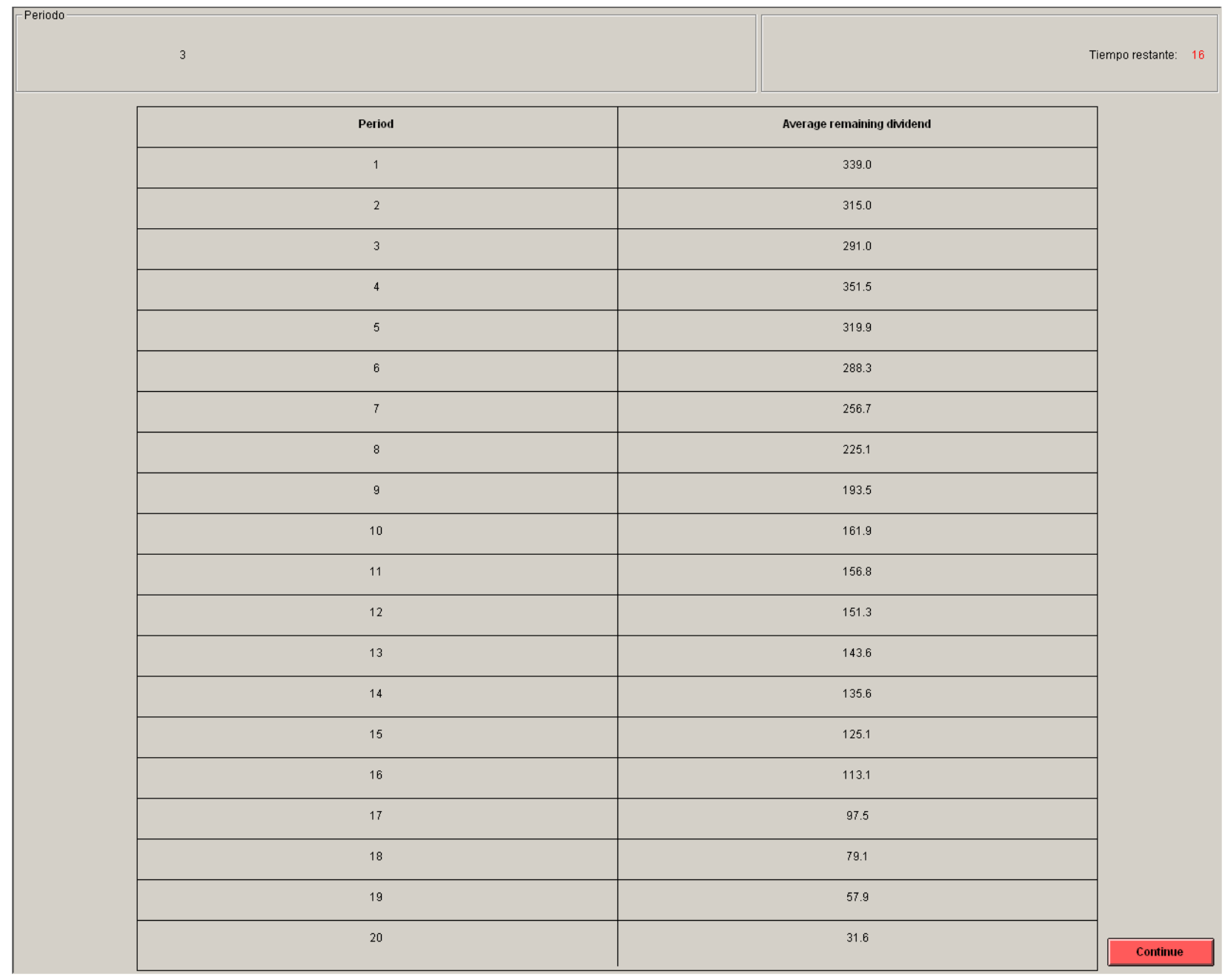

